\title{
8
}
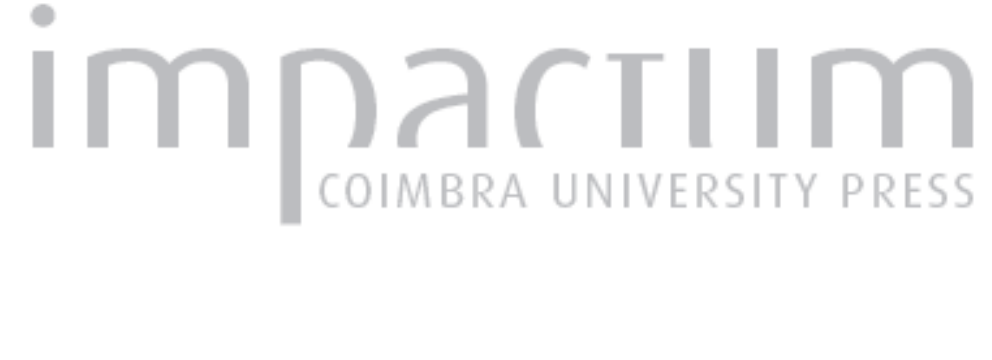

Censual da diocese de Coimbra - século XIV: ANTT: MCO, Ordem de Cristo/Convento de Tomar, liv. 264
Autor(es):
Soalheiro, João
Publicado por: Centro de História da Sociedade e da Cultura
URL persistente:
URI:http://hdl.handle.net/10316.2/39705
DOI:
DOI:http://dx.doi.org/10.14195/1645-2259_6_3

Accessed : $\quad$ 26-Apr-2023 08:22:17

A navegação consulta e descarregamento dos títulos inseridos nas Bibliotecas Digitais UC Digitalis, UC Pombalina e UC Impactum, pressupõem a aceitação plena e sem reservas dos Termos e Condições de Uso destas Bibliotecas Digitais, disponíveis em https://digitalis.uc.pt/pt-pt/termos.

Conforme exposto nos referidos Termos e Condições de Uso, o descarregamento de títulos de acesso restrito requer uma licença válida de autorização devendo o utilizador aceder ao(s) documento(s) a partir de um endereço de IP da instituição detentora da supramencionada licença.

Ao utilizador é apenas permitido o descarregamento para uso pessoal, pelo que o emprego do(s) título(s) descarregado(s) para outro fim, designadamente comercial, carece de autorização do respetivo autor ou editor da obra.

Na medida em que todas as obras da UC Digitalis se encontram protegidas pelo Código do Direito de Autor e Direitos Conexos e demais legislação aplicável, toda a cópia, parcial ou total, deste documento, nos casos em que é legalmente admitida, deverá conter ou fazer-se acompanhar por este aviso. 


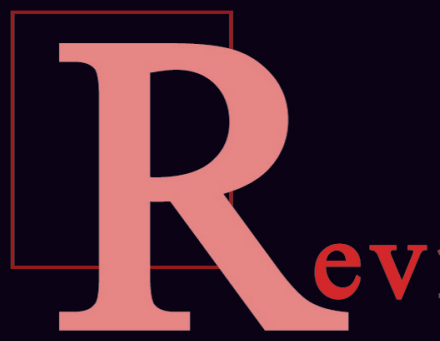

\section{da Sociedade e da Cultura}

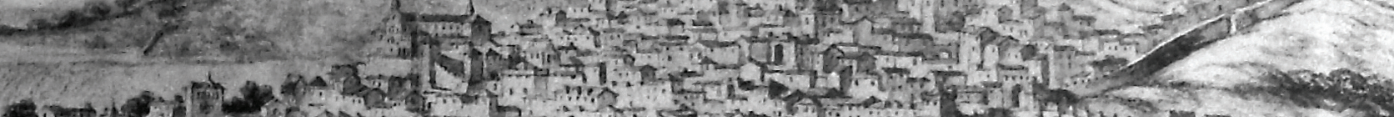

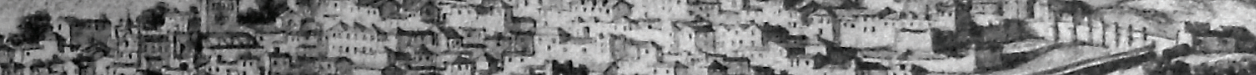

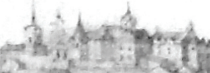

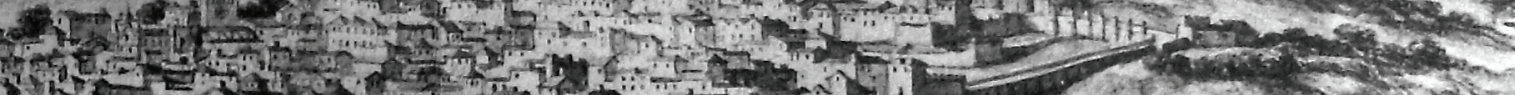

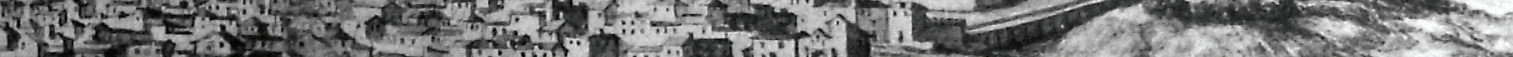

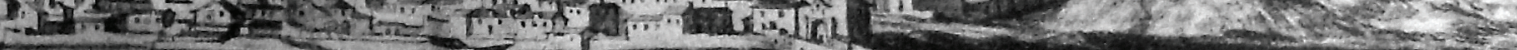

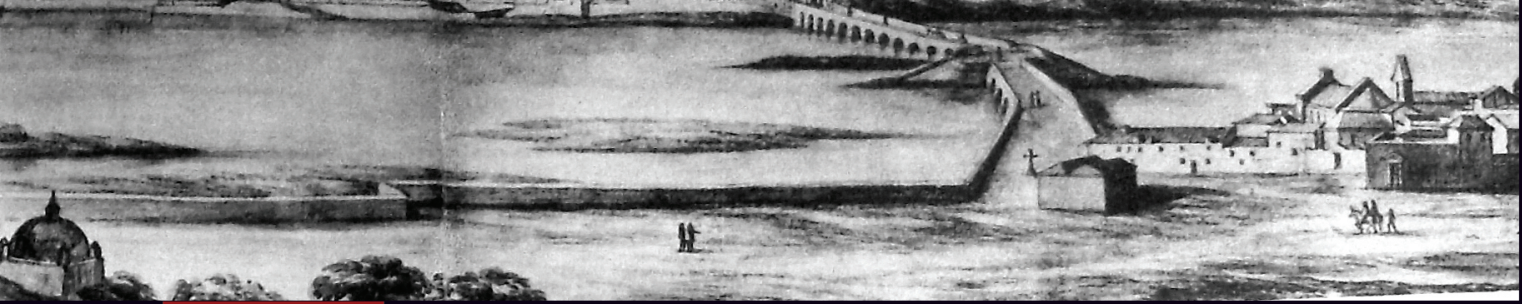

Centro de História da Sociedade e da Cultura Universidade de Coimbra

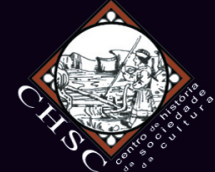




\title{
Censual da Diocese de Coimbra - século XIV ANTT: MCO, Ordem de Cristo/Convento de Tomar, liv. 264
}

\author{
João Soalheiro* \\ Secretariado Nacional dos Bens Culturais da Igreja
}

\begin{abstract}
«Censura e Censuria. Com estes termos se explicam os direitos, rendas e pensões que as catedrais deviam receber, anualmente, das igrejas e mosteiros do bispado. A isto chamaram também jantares, colheitas, visitações, procurações ou paradas [...]; [...] os livros censuaes se começaram a escrever e neles se lançaram todas as censorías e foragens, que as ditas igrejas deviam pagar aos bispos, e seus clérigos ou cabidos. Destes censuaes nos restam alguns; incluídos outros nos que hoje chamam tombos. Uns e outros nada
\end{abstract}

* Doutorando em Letras, área de História, especialidade de História da Idade Média, na Faculdade de Letras da Universidade de Coimbra e bolseiro da Fundação para a Ciência e a Tecnologia, ao abrigo do POCTI 2010, Formação Avançada para a Ciência - Medida IV.3. Membro do Centro de Estudos de História Religiosa, da Universidade Católica Portuguesa, e colaborador do Centro de História da Sociedade e da Cultura, da Universidade de Coimbra. Queremos expressar o nosso profundo agradecimento à Senhora Prof. a Doutora Maria Alegria Marques pelas informações relativas aos censuais que se conservam em Coimbra, bem como pelas observações suscitadas em face do manuscrito de Lisboa. Agradecimento que estendemos também ao Mestre João Luís Inglês Fontes pela revisão do texto que neste trabalho editamos. 
mais são que os títulos das tais censuras, direitos ou rendas, que as respectivas igrejas ou mosteiros devem pagar à sé do bispado» ${ }^{1}$.

Os mais antigos censuais conhecidos em Portugal são oriundos da arquidiocese de Braga, que detém, em simultâneo, o conjunto mais significativo de documentos dessa tipologia, ainda que um ou outro não possa considerar-se especificamente censual, mesmo quando reportam prestações que caracterizam aquelas fontes ${ }^{2}$. Além de Braga, também as dioceses de Lamego, do Porto e de Tuy, na vertente outrora portuguesa, que constituiria a chamada Administração de Valença antes de passar a Braga, contam com documentos do género, já editados, que adiante lembraremos. Para as restantes dioceses portuguesas nenhum censual se acha publicado. Não significa isso que não tenham existido, ou até que todos se tenham perdido ${ }^{3}$. Prova-o bem a fonte que neste trabalho fica atendida, um censual da diocese de Coimbra, datável do reinado de D. Fernando I, como veremos, mas que reflecte, naturalmente, a realidade territorial resultante da sentença pontifícia de 1256, que definiu os limites com que a diocese alcançaria os meados do século $\mathrm{XVI}^{4}$. Trata-se de fonte de administração diocesana conimbricense que não se encontra isolada, pois já Avelino de Jesus da Costa, Maria Helena da Cruz Coelho e Saul António Gomes deixaram constância da existência de censuais da diocese de Coimbra, carecidos, no entanto, de estudo ${ }^{5}$.

${ }^{1}$ Cf. Joaquim de Santa Rosa de Viterbo, Elucidário das palavras, termos e frases que em Portugal antigamente se usaram e que hoje regularmente se ignoram. Ed. crítica por Mário Fiúza. 2. a ed.. Porto; Lisboa, Livraria Civilização, 1965, vol. 2, p. 89, s.v. Censo.

${ }^{2}$ Para a história deste instituto de administração diocesana ver Avelino de Jesus da Costa, O bispo D. Pedro e a organização da arquidiocese de Braga. 2. ${ }^{\text {a }}$ ed. revista e melhorada. Braga, Irmandade de São Bento da Porta Aberta, 1997, vol. 1, p. 272-275.

${ }^{3}$ Esse parece ter sido o caso de Évora, pois nenhum censual, ou sequer mero elenco das igrejas diocesanas, se terá conservado, segundo Maria Hermínia Vilar, As dimensões de um poder: A diocese de Évora na Idade Média. Lisboa, Editorial Estampa, 1999, p. 222.

${ }^{4}$ Mais concretamente, até 1545 , quando se deu a criação da diocese de Leiria. Cf. Saul António Gomes, "Leiria-Fátima, Diocese de". In Carlos Moreira Azevedo (dir.), Dicionário de história religiosa de Portugal. [Lisboa], Círculo de Leitores, 2001, vol. 3, p. 74-81. Para as questões relativas à sentença de 1256 ter presente António Domingues de Sousa Costa, Mestre Silvestre e mestre Vicente, juristas da contenda entre D. Afonso II e suas irmãs. Braga, Tipografia Editorial Franciscana, 1963, p. 326-355. 
Que a divulgação do que será, porventura, o mais antigo censual da diocese de Coimbra chegado aos nossos dias resulte em renovado interesse pela história da diocese do Mondego em tempos medievais é o ensejo que nesta hora nos cumpre formular.

\section{Censual: um instrumento antigo de administração diocesana}

A Idade Média conheceu vários instrumentos de administração eclesiástica, porém, nem todos com o mesmo alcance ou sequer com o mesmo percurso, pois, além da diversidade de matérias a que aqueles se destinaram, também com o tempo a burocracia diocesana, e não apenas estritamente episcopal, se complexificaria. Podemos ilustrar a questão, desde logo, com a produção dos cartulários, que se tornaram fundamentais sobretudo, mas não em exclusividade, à defesa jurídica da propriedade de bens fundiários ${ }^{6}$. Outros meios havia, de estrita gestão, como o perdido «libro arrendationis possessionum anniversariorum» do cabido da catedral conimbricense, várias vezes aduzido no Liber Anniversariorum Ecclesiae Cathedralis

${ }^{5}$ Cf. Avelino de Jesus da Costa, "Censual". In Joel Serrão (coord.), Dicionário de história de Portugal. Porto, Livraria Figueirinhas, [s.d.], vol. 2, p. 37-38. Maria Helena da Cruz Coelho, O Baixo Mondego nos finais da Idade Média. [Lisboa], Imprensa Nacional Casa da Moeda, 1989, vol. 1, p. 377-378 e elenco de fontes, no segundo volume. Saul António Gomes, "Coimbra e Santiago de Compostela: Aspectos de um inter-relacionamento nos séculos medievos". Revista Portuguesa de História. Coimbra. 34 (2000) 453-490: 467, nota 29. Do censual registado por Avelino de Jesus da Costa, nada se diz, no artigo citado, a respeito do seu paradeiro, mas será talvez de o identificar com qualquer um dos dois censuais referenciados por Maria Helena da Cruz Coelho, um que se conserva no Arquivo da Universidade de Coimbra (hoje com a cota Cofre 7) e outro pertença da família do Prof. Abel de Andrade. Quanto ao mais tardio, que Saul Gomes data de 1535 e informa encontrar-se fotografado no Instituto de Paleografia da Faculdade de Letras da Universidade de Coimbra, cremos tratar-se do último exemplar referido.

${ }^{6}$ Veja-se, entre outros, Saul António Gomes, In limine conscriptionis: Documentos, chancelaria e cultura no mosteiro de Santa Cruz de Coimbra: Séculos XII a XIV. Viseu, Palimage Editores, 2007, p. 297 e seguintes. 
Colimbriensis (Livro das Kalendas) ${ }^{7}$. Também os inventários podem ser aferidos num mesmo horizonte de responsabilidade ${ }^{8}$.

A um outro nível, recordaremos os róis ou elencos de igrejas, sobretudo os organizados com vista ao exercício (e correlativa fiscalização) do direito de padroado, como o que se sucede ao censual da diocese de Coimbra, que também atenderemos. Neste cenário, cremos ser de relevar a mutação processual da colação de benefícios, ao menos os paroquiais, durante a primeira metade da centúria XIII, tendo em consideração, por exemplo, alguns depoimentos colhidos na Terra da Maia (diocese do Porto), no âmbito das inquirições gerais de 1258. Não se trata apenas de fazer notar que já por meados do século XIII a colação de benefício paroquial envolvia a expedição de carta de apresentação por parte de quem detinha e/ou exercia o direito de padroado, seguida de outra carta de confirmação emanada da chancelaria episcopal, quando o candidato colhia a aprovação do bispo, o que nem sempre sucedia. Trata-se sobretudo de ter presente que tal processo não seria, por então, muito antigo, pois o responsável da igreja de Ramalde (c. Porto), inquirido a respeito dos respectivos títulos de apresentação e de confirmação, respondeu que não dispunha de tais cartas «quia tunc non erat usus Terre». Asserção ainda mais vincada pelo prelado da igreja de São Miguel de Morroca (hoje Leça da Palmeira, c. Matosinhos ${ }^{9}$ ), quando, ao aduzir a mesma razão para o facto de não possuir cartas daquela natureza,

${ }^{7}$ Edição crítica de Pierre David e Torquato de Sousa Soares. Coimbra, Universidade de Coimbra, 1947-1949, por exemplo a páginas 25 e 28 do primeiro tomo; é fonte que doravante designaremos por Livro das Kalendas.

${ }^{8} \mathrm{O}$ mais antigo exemplar que se conhece entre nós, relativo ao tesouro da catedral de Viseu e por certo lavrado na circunstância da entrada em funções de um novo custódio do acervo, data de 1188". Cf. Saul António Gomes, "Livros e alfaias litúrgicas do tesouro da sé de Viseu em 1188". Hvmanitas. Coimbra. 54 (2002) 269-281. Embora tardios, não deixaremos de referir os inventários da catedral de Coimbra, proficientemente estudados por Avelino de Jesus da Costa, "A biblioteca e o tesouro da Sé de Coimbra nos séculos XI a XVI". Boletim da Biblioteca da Universidade de Coimbra. 38 (1983) 1-219.

${ }^{9}$ Cf. Cândido Augusto Dias dos Santos, O censual da mitra do Porto: subsídios para o estudo da diocese nas vésperas do Concílio de Trento. Porto, Câmara Municipal do Porto, 1973, p. 70. 
reiterava «quia tunc non erat usus Terre», acrescentando «quod prelati ecclesiarum haberent inde cartas $\rangle^{10}$.

$\mathrm{O}$ recurso a censuais enquanto instrumentos de administração diocesana tem de considerar-se prática antiga, que não apenas bem enraizada na vida das dioceses, à vista do acervo que adiante fica apontado, sem dúvida tão-somente parte daqueles que terão existido nas dioceses portuguesas ${ }^{11}$. Com efeito, no território de Braga conservaram-se vestígios de pagamentos de prestações à igreja catedral pelo menos desde o primeiro terço do século XI, o que não invalida vigência anterior, como tem de ser admitido por confronto com a tradicional organização diocesana, por mais mal conhecida que ela seja, entre nós, à míngua de fontes ${ }^{12}$. A solvência de tais prestações obriga também a admitir escrita organizada, independentemente de quase nada sabermos para período tão alto. De facto, o pleito movido pelo prelado de Lugo contra certos colonos da igreja de Braga, em 1025, informa o bastante para que se tenha por firme a existência de cartório organizado na

${ }^{10}$ Cf. Portugaliae Monumenta Historica a saeculo octavo post Christum usque ad quintumdecimum: Inquisitiones. Org. por Alexandre Herculano. Lisboa, Academia das Ciências de Lisboa, 1888, p. 462b, 470b. Essa circunstância levaria D. Afonso III a medidas que teremos de considerar relevantes e que alcançariam tradução no chamamento à corte dos clérigos envolvidos (os que ficam referenciados e ainda outros), bem como na reformulação dos trâmites processuais de apresentação aos benefícios paroquiais, num exercício de plena afirmação dos direitos régios. Cf. Arquivo Nacional da Torre do Tombo / Direcção-Geral de Arquivos (doravante ANTT): Colecção das Gavetas, gav. 19, mç. 14, n. ${ }^{\circ} 2$.

${ }^{11}$ Relacionados com os censuais haveria também, circunstancialmente, outros documentos, como o parece garantir um elenco conservado no fundo do cabido da catedral de Coimbra do Arquivo Nacional da Torre do Tombo, datável do século XIII e talvez anterior a 1256, pois os valores relativos às igrejas colegiadas da cidade de Coimbra nada têm que ver com a composição celebrada naquele ano e que adiante referiremos. $\mathrm{O}$ documento elenca largas dezenas de igrejas diocesanas, ou indivíduos responsáveis por elas, consignando-lhes as prestações, registo que se reporta à percepção das mesmas em determinado momento, pese a data não se achar expressa. Cf. ANTT: Corporações Religiosas, Cabido da Sé de Coimbra, 1. ${ }^{\mathrm{a}}$ inc., mç. 20, n. ${ }^{\circ} 25$. Nesse sentido, poderemos aproximar, de algum modo, a fonte conimbricense ao que Avelino de Jesus da Costa designou como «Censual de D. Jorge da Costa», que apresenta a bem elucidativa epígrafe: «Lyvro do reçebimento Dantre Douro e Minho das colheytas...». Cf. Avelino de Jesus da Costa, O bispo D. Pedro e a organização da arquidiocese de Braga, vol. 2, p. 329.

${ }^{12}$ Cf. Ibidem, vol. 1, p. 273-274. 
catedral bracarense, pois que ao seu thesaurus recorreu o representante do antístite lucense para atestar a sua razão, alicerçada na documentação aí custodiada ${ }^{13}$.

Muitos anos depois e enquanto responsável pelo governo da diocese do Porto, São Geraldo utilizou uma «cartam in que erant nomina omnium ecclesiarum et monasteriorum Portugalensis diocesis ut sciret episcopus ex singulis quid secundum debitum esset accepturus», isto é, teve à sua disposição um censual daquela circunscrição diocesana, que, a exemplo do que se passava em Braga, elencava as igrejas e os mosteiros da diocese, consignando a cada uma daquelas instituições o que devia pagar à igreja catedral ${ }^{14}$. Tal documento talvez tenha sido elaborado, se não lhe era mesmo anterior, por iniciativa do bispo D. Pedro, que tutelou a vizinha diocese do Porto, depois do decesso do bispo D. Sesnando ${ }^{15}$. Tenha-se em consideração que ao restaurador da diocese de Braga atribuiu Avelino de Jesus da Costa a realização de idêntico e fundamental instrumento de administração eclesiástica, relativo à sua Igreja, documento que, como é sabido e já deixámos assinalado, é não apenas o mais antigo e importante de quantos do género se conservam em Portugal, como não tem, para a mesma época e com a

${ }^{13}$ Cf. Ibidem, p. 301.

${ }^{14}$ Conforme testemunho de 1101, produzido em consequência de acto de visitação episcopal ao mosteiro de Santo Tirso de Riba de Ave, protagonizado por São Geraldo. Trata-se de documento que Avelino de Jesus da Costa soube valorizar contra o entendimento que lhe conferira Carl Erdmann, O Papado e Portugal no primeiro século da história portuguesa. Coimbra, Instituto Alemão da Universidade de Coimbra, 1935, p. 81. Cf. Avelino de Jesus da Costa, O bispo D. Pedro e a organização da arquidiocese de Braga, vol. 2, p. 426-428, n. ${ }^{\circ} 68$.

${ }^{15}$ Encontra-se por justificar a razão da perda de prelado residencial em 1070, à vista da imediata restauração da diocese de Braga e da diocese de Lamego e quando o processo relativo a Coimbra corria o seu curso. De qualquer modo, ao último bispo do Porto da centúria XI, D. Sesnando, dever-se-á tributar não pequena responsabilidade na concretização do impulso reformador impresso às igrejas do reino leonês durante o reinado de Fernando Magno, sobretudo na sequência do Concílio de Coyanza (hoje Valencia de D. Juan), em 1055. Acompanhou aí o prelado, que subscreveu os respectivos cânones, o monge Randulfo do mosteiro da Vacariça, que recolheu ao cenóbio cópia das respectivas actas, mais tarde incorporadas no Livro Preto da sé de Coimbra. Cf. Idem, "Coimbra: centro de atracção e de 
mesma dimensão, ainda segundo o ilustre medievalista da Universidade de Coimbra, qualquer paralelo na Cristandade ocidental ${ }^{16}$.

Apesar dos testemunhos referentes a Braga e ao Porto, nada de semelhante é conhecido, pela mesma altura, para as restantes dioceses do território portucalense. E será, talvez, tanto mais de estranhar essa ausência quanto é sabido ter também o bispo D. Crescónio, sucessor de D. Paterno na sede episcopal conimbricense e único bispo em exercício na área portucalense do reino de Leão durante todo o seu pontificado, administrado a diocese do Porto (e porventura a de Braga) durante a longa vacância que se seguiu à deposição do bispo D. Pedro, apenas removida com a eleição, sagração e entronização do chantre de Toledo e antigo monge de Moissac, o cluniacense São Geraldo ${ }^{17}$. Pelo que não cremos temerário considerar que o censual utilizado por São Geraldo, e cuja formulação nada lhe terá ficado a dever, tendo em conta o percurso do prelado nos primeiros anos do seu governo,

irradiação de códices e de documentos, dentro da Península, nos sécs. XI e XII”. In Actas das II Jornadas luso-espanholas de história medieval. Porto: Instituto Nacional de Investigação Científica, 1990, vol. 4, p. 1310-1313. Do envolvimento de D. Sesnando em toda essa obra de reforma eclesial também dá testemunho a sua firma nas actas do Concílio de Compostela, de 23 de Outubro de 1063, que os padres conciliares enviaram ao bispo de León. Cf. Colección documental del Archivo de la Catedral de León. IV: 1032-1109. Ed. por Jose Manuel Ruiz Asencio. León: Centro de Estudios e Investigación «San Isidoro», 1990, p. 343-346, doc. 1127. Relativamente à administração da diocese do Porto pelo bispo D. Pedro, recordaremos que, antes de Junho de 1082, o prelado bracarense estabeleu o diácono Galindo no arcediagado da Maia e que, em 1087, a dotação da igreja de São Martinho de Cedofeita foi-lhe outorgada pelos fundadores. Cf. Avelino de Jesus da Costa, O bispo D. Pedro e a organização da arquidiocese de Braga, vol. 1, pp. 292-293.

${ }^{16}$ Cf. Ibidem, vol. 1, pp. 287-292.

${ }^{17}$ Mostra-o, com efeito, no exercício desse encargo o facto de ter sido a D. Crescónio que os patronos do mosteiro de Santo Tirso de Riba de Ave se dirigiram a solicitar a confirmação da eleição abacial que haviam feito na pessoa de Gaudemiro, o que teve lugar em 1092. Cf. António Caetano de Sousa, Provas da historia genealogica da Casa Real portugueza. Tomo III, parte II. Reed. Coimbra, Atlântida - Livraria Editora, L.da, 1949, p. 105-123, n. ${ }^{\circ} 41$, em particular 120-121. Como também o manifesta o acto da dedicação da igreja do mosteiro de São João de Riba de Douro, hoje freguesia de Alpendurada (c. Marco de Canaveses), cuja cronologia não é possível precisar, dentro do episcopado daquele prelado (1092-1098). Cf. Portugaliae Monumenta Historica a saeculo octavo post 
não terá sido desconhecido do bispo conimbricense, mal se entendendo que não tivesse ao seu serviço semelhante documento relativo à sua própria diocese.

Se é verdade que pela época em que nos situamos a administração corrente das dioceses também estava a cargo de arcediagos, que detinham inclusive o poder jurisdicional de «ligar e desligar» no âmbito das circunscrições a que presidiam ${ }^{18}$, não é menos certo que aos mesmos estava vedada a realização de diferentes actos peculiares à ordem pontifica $~^{19}$. Tal os casos, entre outros, da dedicação de igrejas, da sagração dos óleos, da conferência de ordens sacras, actos que, ao serem servidos por rituais específicos, configuraram um peculiar livro litúrgico, próprio dos bispos, a que se chamou Pontifical ${ }^{20}$. Nesse sentido, convirá ter também presente a circunstância de as prestações registadas em censuais diocesanos não poderem ser confundidas com outros direitos que os arcediagos detivessem nas igrejas e nos mosteiros dos territórios que lhes estavam confiados. Pelo que, fosse ao próprio bispo, fosse a um prelado estranho a quem estivesse cometida a responsabilidade última da administração diocesana, ou a legítimo representante, as igrejas e os mosteiros dos espaços diocesanos, não dispondo de

Christum usque ad quintumdecimum: Diplomata et chartae. Org. por Alexandre Herculano. Lisboa, Academia das Ciências de Lisboa, 1867, doc. 898. Sobre a instalação de São Geraldo em Braga ter presente Avelino de Jesus da Costa, "A vacância da sé de Braga e o episcopado de São Geraldo (1099-1108)”. Acção Católica. Braga. 76 (1991) 99-122.

${ }^{18}$ Para a discussão da problemática ver Anne Lefevre-Teillard, "Ordre ou juridiction? À propos du pouvoir d'excommunier des archidiacres (fin XII ${ }^{\mathrm{e}}$ - début XIII ${ }^{\mathrm{e}}$ siècle)". In Giles Constable; Michel Rouche, ed. lit-Auctoritas: Mélanges offerts au professeur Olivier Guillot. Paris, Presses de l'Université Paris-Sorbonne, 2006, p. 615-623.

${ }^{19}$ Circunstância que diferencia fundamentalmente o papel dos arcediagos do dos pontífices. Cf. Aires A. Nascimento, Hagiografia de Santa Cruz de Coimbra: Vida de D. Telo, Vida de D. Teotónio, Vida de Martinho de Soure. Lisboa, Edições Colibri, 1998, p. 23-25 e, no caso, nota 14.

${ }^{20} \mathrm{Cf}$. Éric Palazzo, Histoire des livres liturgiques: Le Moyen Age: Des origines au XIII siècle. Préface de Pierre-Marie Gy. Paris, Beauchesne Éditeur, 1993, p. 204-220. Joaquim O. Bragança, "Um pontifical de Braga do séc. XIII". Boletim Internacional de Bibliografia Luso-Brasileira. Lisboa. 4 (1963) 637-645. Idem, "Pontifical de Braga do séc. XII, Porto, Bibl. Mun. ms. 1134, fol. 1-42”. Didaskalia. Lisboa. 7 (1977) 309-398. 
título que a isso os eximisse, teriam sempre de saldar as prestações devidas às respectivas catedrais, independentemente de outras obrigações a que também estariam sujeitos, como sucedia por respeito aos arcediagos ${ }^{21}$.

Seja como for, Coimbra, em finais do século XI, tem de considerar-se diocese bem organizada e com um quadro governativo pujante, não só como efeito de uma restauração recente, tornada efectiva a partir de 1080, embora desejada e projectada com anterioridade ${ }^{22}$, mas também em resultado da complexidade administrativa que o próprio papa Pascoal II sancionaria, quando formalizou ao prelado conimbricense, pela bula Apostolice sedis, de 1101, a cura conjunta das dioceses de Lamego e Viseu (mas não da de Idanha), o que alguns documentos indiciam, quanto a nós, ser já uma realidade alguns anos antes da intervenção pontifícia ${ }^{23}$.

Entendemos, no entanto, ser bem mais provável que a ausência de testemunhos sobre a existência, pela mesma época, de censual (ou censuais) a Sul do Douro possa apenas ficar a dever-se a perda dos respectivos registos mais antigos, porventura mesmo justificada pelas necessárias actualizações

${ }^{21}$ Remetemos a alguns dos mais antigos casos que se encontram documentados, respectivamente de 1085 e de 1087, relativos à dotação das igrejas de São Mateus de Soalhães (f. Oliveira, c. Vila Nova de Famalicão, na Arquidiocese de Braga) e de São Martinho de Cedofeita (Porto). Cf. COSTA - O bispo D. Pedro e a organização da arquidiocese de Braga, vol. 2, p. 403-405, doc. 41 e 42, e p. 411, doc. 50. Por razão da sua clareza, importará atender ao registo consignado pelo último documento: «Et redam vobis vestro jantare et ad ille archidiaconus II solidos». Relativamente a títulos de isenção, foram vários os mosteiros que os alcançaram por acordo com os prelados diocesanos. Lembraremos, entre outros possíveis, os casos do mosteiro de São Salvador de Paço de Sousa, ao tempo do bispo D. Hugo do Porto, e do mosteiro de São Cristóvão de Requião, pouco depois de D. João Peculiar ter sido eleito para a cátedra arquiepiscopal de Braga. Cf., respectivamente, Documentos medievais portugueses: Documentos particulares. Vol. IV/1: A. D. 1116-1123. Ed. por Rui Pinto de Azevedo e Avelino de Jesus da Costa. Lisboa: Academia Portuguesa da História, 1980, doc. 20, e COSTA - O bispo D. Pedro e a organização da arquidiocese de Braga, vol. 2, p. 432, doc. 73. Neste último documento pode ler-se: «pro illo iantuculo de meo monasterio quod dimittitis quod nunquam amplius nec vos nec successores vestri illud requiratis».

${ }^{22}$ Cf. Idem, "Coimbra: centro de atracção e de irradiação...", p. 1315.

${ }^{23}$ Cf. Carl Erdmann, Papsturkunden in Portugal. Berlin, 1927, p. 154-156, doc. 2. 
a que a restauração das dioceses de Lamego, Viseu, Lisboa, Évora e Guarda e correlativos processos de redimensionação territorial, até à centúria XIII, a cada passo obrigou ${ }^{24}$. A diocese de Coimbra, como é bem sabido, esteve envolvida em quase todas as grandes alterações da estrutura eclesiástica do reino de Portugal, por aquela época, tendo perdido, além da administração das dioceses de Lamego e de Viseu, territórios para as dioceses do Porto, da Guarda e de Lisboa. Perante novas realidades, sem dúvida que terá sido impositiva, ao exercício dos responsáveis diocesanos, a necessidade de adequar os instrumentos de governo, movimento com que haverá que relacionar a génese da fonte que nos ocupa, mesmo se indirectamente.

Além do que fica dito, e ainda num quadro organizativo de estrita administração diocesana, importará também relevar que Coimbra foi a primeira diocese entre as congéneres portuguesas, e uma das que mais cedo o fez entre as demais peninsulares, a promover a divisão entre a mesa pontifical e a mesa capitular, na proporção de dois terços para um, respectivamente, dos rendimentos de que era geradora ${ }^{25}$. Tal iniciativa, que traduz um inequívoco amadurecimento das estruturas diocesanas e das pessoas que lhe

${ }^{24}$ Para uma visão rápida da questão consulte-se Bernardo Sá Nogueira, "Geografia eclesiástica. I. Época medieval". In Carlos Moreira Azevedo (dir.), Dicionário de história religiosa de Portugal. [Lisboa], Círculo de Leitores, 2000, vol. 2, p. 289-294. Quanto ao processo de restauração diocesana aos meados do século XII ver Maria Alegria Fernandes Marques, "A restauração das dioceses de Entre Douro e Tejo e o litígio Braga-Compostela". In Actas do 2. ${ }^{\circ}$ Congresso histórico de Guimarães. [Guimarães], Câmara Municipal de Guimarães; Universidade do Minho, [1997], vol. 5, p. 51-84. Pelo que se reporta a conflitos sobre limites territoriais ter em consideração, quanto ao Porto, Miguel de Oliveira, "Os territórios diocesanos". Lusitania Sacra. Lisboa. 1 (1956) 29-50 e Cândido Augusto Dias dos Santos, O censual da mitra do Porto, p. 21-28, e, quanto à Guarda, A. Domingues de Sousa Costa, Mestre Silvestre e mestre Vicente, juristas da contenda entre D. Afonso II e suas irmãs, p. 293-355. Seja como for, o conjunto de questões que tais processos envolvem, nem todas dilucidadas ainda com o mesmo vigor, carece de ser atendido numa estrita perspectiva conimbricense.

${ }^{25}$ Idêntica repartição encontra-se documentada em Palencia desde 1100, Oviedo desde 1106, em León desde 1120, em Zaragoza desde 1122, para apenas referirmos os casos mais antigos. Cf. Francisco Javier Pérez Rodríguez, La iglesia de Santiago de Compostela en la Edad Media: El cabildo catedralicio (1100-1400). [S.1.], Xunta de Galicia, [D.L. 1996], p. 28-29. A Santa Sé faria política sua a implementação da repartição das rendas, como bem 
deram corpo, com tudo o que isso tem necessariamente de significar incluído o conhecimento dos valores a repartir, isto é, computados, e não apenas através de censuais, dada a diversidade de rendimentos a ter em consideração -, pertenceu ao bispo D. Gonçalo Pais, segundo acto de sua iniciativa arquivado no magno cartulário catedralício ${ }^{26}$. Muito antes, há-de ainda observar-se, que idêntica medida fosse implementada na arquidiocese de Braga, o que aconteceu apenas em $1145^{27}$ e provavelmente a contragosto de D. João Peculiar, a avaliar pelas circunstâncias que os documentos interessados na questão permitem aferir e que noutro lugar retomaremos.

Ironia da vida, o que também toca às instituições, a diocese de Coimbra solicitaria auxílio à de Braga, corria já o início da centúria XIII, para alcançar um texto que lhe servisse de modelo para a divisão das rendas, como consta do texto concordatário de 1210 , celebrado entre o bispo D. Pedro e os capitulares $^{28}$. O que talvez signifique - muito embora ao pedido assinalado possa ser conferido outro entendimento que o admitido comummente - que a iniciativa, sem dúvida pioneira, de D. Gonçalo Pais e que seria sancionada pelo sucessor, como passamos a expor, não tenha vingado. Uma e outra vez. Essa circunstância poderá, talvez, colorir um pouco melhor o quadro da reforma pastoral que alguns agentes do governo eclesial conimbricense, com manifesta oposição de outros, intentaram a Sul do Douro na década de

o demonstra, entre tantos exemplos que podem referir-se em contexto hispânico, o caso da diocese de Barcelona. Cf. José María Marti Bonet, "El papa Alejandro III y la «Mensa Episcopal» de Barcelona”. Anthologica Annua. Roma. 24-25 (1977-1978) 357-380 .

${ }^{26}$ Cf. Livro Preto: Cartulário da Sé de Coimbra: Edição crítica, texto integral. Direcção e coordenação editorial de Manuel Augusto Rodrigues, coordenação científica de Avelino de Jesus da Costa. Coimbra, Arquivo da Universidade de Coimbra, 1999, doc. 627.

${ }^{27} \mathrm{Cf}$. Avelino de Jesus da Costa, O bispo D. Pedro e a organização da arquidiocese de Braga, vol. 1, p. 308, que considera, no entanto, ter sido Braga a primeira diocese portuguesa a instituir as duas mesas.

${ }^{28}$ Cf. Idem, "D. João Peculiar co-fundador do mosteiro de Santa Cruz, bispo do Porto e arcebispo de Braga". In Santa Cruz de Coimbra do século XI ao século XX: Estudos no IX centenário do nascimento de S. Teotónio, 1082-1982. Coimbra, [s.n.], 1984, p. 59-83, no caso p. 67 e p. $82-83$. 
vinte do século XII e que, por razões não de todo esclarecidas, se viu questionada em algum momento. E porventura mais do que uma vez. Como é sabido e bem o demonstra a documentação da diocese do Porto, a institucionalização de duas mesas, a episcopal e a capitular, trouxe consigo a consequente secularização dos cabidos, de que o término da vida em comum terá constituído, porventura, o seu mais expressivo sinal ${ }^{29}$. E esse parece-nos ser o problema dinamizador das tensões vividas nas estruturas nevrálgicas da diocese de Coimbra ao longo de parte muito significativa do século XII.

É nesse horizonte que lemos os acontecimentos em torno da promoção do arcediago bracarense Bernardo à titularidade e regência da sede episcopal de Coimbra, contra os desejos dos que apoiavam o arcediago Telo, do clero local, cenário que, aberto com a vacância ditada pelo decesso de D. Gonçalo Pais, em 17 de Abril de $1127^{30}$, também se soube moldar a um novo protagonismo no governo político do território portucalense, saído do recontro de

${ }^{29}$ Cf. Censual do cabido da sé do Porto: códice pergaminaceo existente na Biblioteca do Porto. Ed. por João Grave. Porto, Imprensa Portuguesa, 1924, p. 493-494. Ver, no mesmo sentido, Pérez Rodríguez, La iglesia de Santiago de Compostela en la Edad Media, p. 28.

${ }^{30}$ Cf. Livro das Kalendas, vol. 1, p. 205. O ano registado no necrológio catedralício, conquanto apareça não raro transmudado ao seguinte, 1128, pela historiografia, deve considerar-se correcto, pois desde 23 de Maio de 1127, data em que a rainha Teresa doou o mosteiro de Vimieiro a Cluny, nenhum diploma dos governantes portucalenses ostenta a confirmação do antístite. Dá-se ainda a circunstância de um documento de 31 de Março de 1128, pelo qual D. Teresa agraciou um casal com bens em Fráguas (c. Vila Nova de Paiva), em território de administração do bispo de Coimbra, se encontrar confirmado por D. Telo, arcediago de Coimbra, por D. Odório, prior de Viseu, e por D. Moninho, arcediago de Lamego, mas sem que se faça qualquer referência ao bispo de Coimbra. Cf. Documentos medievais portugueses: Documentos régios: Documentos dos condes portugalenses e de D. Afonso Henriques, A. D. 1095-1185. Vol. I. Ed. por Rui Pinto de Azevedo. Lisboa, Academia Portuguesa da História, 1958, doc. 75 e 81. Se bem interpretamos, o resultado alcançado, pelo que ao provimento da cátedra diocesana diz respeito, longe de reflectir apenas a mudança política ditada pelo resultado da batalha de São Mamede, terá também de ler-se à luz de um processo eleitoral sofrido de dissenção entre os que estavam chamados a dar-lhe forma, nomeadamente no seio do próprio clero conimbricense. Só isso justifica, em nossa opinião, que, no espaço de mais de um ano, D. Teresa não tenha tido possibilidade de dar o seu placet a um eleito para assumir o governo da diocese. 
São Mamede, em 24 de Junho de 1128. A facção vencida na disputa da cátedra conimbricense não se conformou, muito menos se submeteu à nova ordem emergente, empenhando-se na fundação de um mosteiro de cónegos regrantes, tão reivindicado, nos textos a que soube dar vida, como o da verdadeira observância canonical, precisamente contra os protagonistas do serviço cultual catedralício ${ }^{31}$.

Seja como for, e mesmo carecendo de documentação pertinente que o corrobore, D. Bernardo terá querido e sabido chamar a si a reforma intentada pelo seu antecessor, dando-lhe continuidade, pois que ao antigo arcediago bracarense - não a D. Gonçalo, nem a qualquer outro prelado - tributou o grémio capitular de Coimbra a implantação daquela medida ${ }^{32}$. Mas talvez em vão, mais uma vez, pois a repartição das rendas pelas duas mesas ocuparia ainda os responsáveis diocesanos em finais do século XII, como referimos. Não sem que fosse retomada de novo um século mais tarde, já no episcopado de D. Aymeric Ébrad, muito embora em contexto algo diverso, por entretanto outros rendimentos terem aparecido, mantendo-se, até então, em administração comum. Em resposta a solicitação do cabido da catedral de Coimbra, o papa Bonifácio VIII mandataria o prior do mosteiro de São Jorge para que, averiguada a legitimidade das informações prestadas pelos

${ }^{31}$ Cf. Aires A. Nascimento, "Santa Cruz de Coimbra: As motivações de uma fundação regular". In Actas do 2. ${ }^{\circ}$ congresso histórico de Guimarães. [Guimarães], Câmara Municipal de Guimarães; Universidade do Minho, [1997], vol. 4, p. 116-127 e Saul António Gomes, In limine conscriptionis: Documentos, chancelaria e cultura no mosteiro de Santa Cruz de Coimbra, p. 105-119, onde, além de a questão da fundação regrante se encontrar revisitada, com perspectivas que importará considerar, se apontam as contribuições historiográficas ao tema, contando-se entre as mais recentes as dissertações de doutoramento de Armando Martins e de Agostinho Figueiredo Frias.

${ }^{32}$ Isto apesar do que pretendeu o próprio prelado D. Gonçalo Pais, como fica manifesto no documento do Livro Preto, supra referido: «Istam autem confirmationem privilegii, ob remedium meorum delictorum, atque in memoriam et honorem mei nominis auctorizo et mea propria manu roboro». Essa memória seria cultivada pelos cónegos conimbricenses, mas por relação ao seu sucessor. Com efeito, o Livro das Kalendas, vol. 1, p. 70, na ementa que comemorava o óbito de D. Bernardo ( $† 27$ de Janeiro de 1146), registou: «in tempore cuius canonici habuerunt terciam partem integram totius episcopatus et episcopus duas partes ut expensas faciat in omnibus questionibus et negociis ecclesie Colimbriensis». 
cónegos e salvaguardados os interesses das partes, desse confirmação pontifícia à nova repartição, o que o pontífice ordenou pela bula Petitio dilectorum filiorum, de 22 de Novembro de $1295^{33}$.

\section{Censuais diocesanos portugueses}

Entre os censuais bracarenses produzidos até ao final do século $\mathrm{XV}$, a que Avelino de Jesus da Costa dedicou a sua dissertação de doutoramento, ainda hoje obra incontornável da historiografia medieval portuguesa, contam-se: um relativo às paróquias do Entre-Lima-e-Ave, em cópia de meados do século XII, porventura actualizada e decerto parte de mais vasto documento ${ }^{34}$, que o mesmo investigador atribuiu ao bispo D. Pedro e cuja datação, relacionando-o com a sagração da catedral em 27 de Agosto de $1089^{35}$, fixou criticamente entre Outubro de 1085 e Agosto de 1089 ${ }^{36}$; um censual da Terra de Guimarães e da Terra de Montelongo, segundo exemplar, talvez

${ }^{33}$ Cf. ANTT: Corporações Religiosas, Cabido da Sé de Coimbra, 2. ${ }^{a}$ inc., m. 42, n. ${ }^{\circ} 1732$, documento referido por Miguel Ribeiro de Vasconcelos, Noticia historica do mosteiro da Vacariça doado á sé de Coimbra em 1094, e da serie chronologica dos bispos desta cidade desde 1064, em que foi tomada aos mouros. Continuação da Parte segunda. Lisboa, Typographia da Academia, 1855, p. 5, muito embora com erro na data, pois que não é de 1294, dado que Bonifácio VIII, eleito em 24 de Dezembro daquele ano, só em 23 de Janeiro de 1295 foi entronizado. No mesmo maço encontra-se outro exemplar da referida bula, sob o n. ${ }^{\circ} 1721$. O alcance da repartição por então realizada aparece assim definido no documento pontifício: «iura patronatus iurisdictiones fructus redditus et prouentus terras possessiones et nonnulla alia bona ad eos communiter spectantia pro utilitate mensarum tam Episcopi quam Capituli pro se suisque successoribus concorditer diuiserunt sicut alia bona ipsorum inter suos predecessores fuerunt ab antiquis temporibus iam diuisa...».

${ }^{34} \mathrm{Cf}$. Avelino de Jesus da Costa, O bispo D. Pedro e a organização da arquidiocese de Braga, vol. 2, p. 7-231, segundo Arquivo Distrital e Biblioteca Pública de Braga (ADBPB): Gaveta $1 .{ }^{a}$ das Igrejas, n. ${ }^{\circ}$ 1, também transcrito no Tombo do Cabido, fol. $142-144 \mathrm{v}$, do mesmo Arquivo.

${ }^{35}$ Cf. Idem, Dedicação da sé de Braga: 28 de Agosto de 1089: Resposta a Bernard F. Reilly in «The Kingdom of León-Castilla under King Alfonso VI. 1065-1109». Princeton University Press. 1988. Braga, Cabido Metropolitano e Primacial de Braga, 1991.

${ }^{36} \mathrm{Cf}$. Idem, O bispo D. Pedro e a organização da arquidiocese de Braga, vol. 1, p. $275-280$. 
o próprio original, datado de 28 de Setembro de $1259^{37}$; um da Terra de Panoias, do século XIII ${ }^{38}$; um do couto de Braga e da Terra de Faria, do século XIV, copiado num tombo datado de 27 de Abril de 138739; um outro do cabido de Braga, cuja datação crítica foi estabelecida por Alberto Feio entre [1369-1380 $]^{40}$; e, por fim, o censual dito «de D. Diogo de Sousa», mas que Avelino de Jesus da Costa atribuiu ao arcebispo D. Jorge da Costa e datou de $[1493]^{41}$.

Para Lamego temos a referir o chamado «Leituário da Sé de Lamego», anterior a 1282, em virtude de algumas ementas datadas, por certo aí lançadas posteriormente à produção do documento, e que logrou chegar aos nossos dias através de sucessivos traslados. Foi editado por Alfredo Pimenta, mas sem qualquer indicação a respeito do manuscrito que lhe serviu de base, hoje desconhecido ${ }^{42}$. Pela época a que respeita, podemos ainda juntar-lhe, pese o carácter restritivo da fonte, um pequeno e singular censual do tesouro

${ }^{37}$ Cf. Ibidem, vol. 2, p. 232-258, segundo ADBPB: Gaveta 1. ${ }^{\text {a }}$ das Propriedades do Cabido, n. ${ }^{\circ} 34$.

${ }^{38}$ Cf. Ibidem, vol. 2, p. 269-281, segundo ADBPB: Colecção Cronológica, caixa 4, n. ${ }^{\circ} 51$.

${ }^{39}$ Cf. Ibidem, vol. 2, p. 282-286, segundo ADBPB: Tombo do Cabido, fol. 134v-135.

${ }^{40}$ Cf. Ibidem, vol. 2, p. 287-328, segundo ADBPB: Tombo do Cabido, fol. 1v-30r e 64r e seguintes.

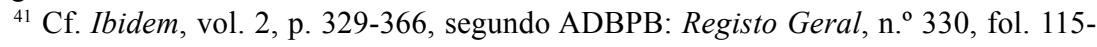
-138 .

${ }^{42}$ Cf. António da Assunção Meireles, O.S.B., Memórias do mosteiro de Pombeiro. Publicadas e prefaciadas por António Baião; Leituário da sé de Lamego. Publicado por Alfredo Pimenta. Lisboa, Academia Portuguesa da História, 1942, p. 225-255. O texto que serviu de lição à edição que fica referenciada terá sido o traslado feito em Lamego, em 28 de Julho de 1691, de uma pública-forma de 1368. Quanto a esta, em 11 de Agosto daquele ano, quando o bispo D. Lourenço (1363-1393) presidia a sínodo diocesano, o cabido da catedral solicitou-lhe autorizasse o traslado em pública-forma de «hvm Leitoario por qve sabiam as rendas, foros e herdades; que o dito Cabb. ${ }^{\circ}$ há e que o dito Leitoario hera escrito em papel, demais que hera já velho que se rompia e estava em ponto de se perder», ao que o prelado deu seguimento, ordenando as diligências necessárias. Na verdade, o Leituário não respeitava apenas ao Cabido, mas também à mesa episcopal, além de que, a par das procurações das igrejas, registava também todo o género de outros bens e direitos pertencentes ao prelado e aos cónegos. Entre as adicções conta-se mesmo um pequeno inventário do tesouro da catedral. 
da catedral lamecense, encabeçado pela epígrafe «Hec sunt cere que pertinent ad thesaurum sedis Lameci», talvez de finais do século XIII, que permanece inédito ${ }^{43}$. No século XVI o censual diocesano seria reformulado, sendo lançado em códice que hoje se conserva no Paço Episcopal, apesar de A. de Almeida Fernandes, que o editou tendo por base uma cópia que fizera à roda de 1942, não saber já, como deixou consignado na introdução, onde se encontraria à data da publicação (1999), presumindo-o perdido, ou em vias disso. Trata-se de fonte que Santa Rosa de Viterbo referenciou como «Censual da Mitra de Lamego» e o seu editor, em trabalhos anteriores, como «Censual do Cabido de Lamego», embora ele não respeite a uma ou a outra das duas mesas, a pontifical e a capitular, a que os rendimentos diocesanos se achavam vinculados, mas sim indistintamente a ambas, o que, além de advertido por Almeida Fernandes, se acha reflectido no título com que foi dado à estampa ${ }^{44}$.

Da diocese do Porto encontram-se também publicados dois censuais. O mais antigo, desafortunadamente truncado, será talvez de finais do século XIII e acha-se integrado no cartulário do cabido da catedral, de meados da centúria seguinte, editado por João Grave, a partir de leitura realizada por um amanuense ${ }^{45}$. O segundo, chamado Censual da Mitra, foi elaborado em 1542, às ordens do bispo D. Frei Baltasar Limpo e na sequência de decisão tomada em sínodo diocesano do ano precedente. Trata-se de censual que documentação contemporânea denominava novo, por confronto com o anterior, ou ainda «do Bispado e das cousas tocantes a mesa pontifical». $\mathrm{Na}$ realidade, além da matéria própria de censual, o códice reúne as mais

${ }^{43}$ Cf. ANTT: Corporações Religiosas, Cabido da Sé de Lamego, liv. 1 (Martirológio-Obituário). Descrição global do códice em Aires A. Nascimento, "Martirológio e obituário da sé de Lamego". In Cristo fonte de esperança: catálogo da exposição do grande Jubileu do Ano 2000. Coordenação científica de Carlos A. Moreira Azevedo e João Soalheiro. Porto, Diocese do Porto, 2000, p. 306-307, n. 199.

${ }^{44}$ Cf. Censual da sé de Lamego: Século XVI. Leitura, transcrição e notas de A. de Almeida Fernandes. Arouca, Associação da Defesa do Património Arouquense, 1999.

${ }^{45}$ Cf. Censual do cabido da sé do Porto, p. 543-582, códice que seria transferido da Biblioteca Municipal para o Arquivo Distrital do Porto, criado em 1932. 
diversas informações relativas a títulos de propriedade, rendas, foros, direitos, obrigações e até emolumentos e taxas. Por outro lado, será de notar que é de carácter diocesano, e não apenas referido à mesa episcopal. Foi publicado e estudado por Cândido dos Santos, que o tomou como base da sua dissertação de doutoramento ${ }^{46}$.

Por fim, da Terra da Vinha e elaborado a mandato do cabido da sé de Tuy, em 1321, conserva-se também um censual, editado e estudado por José Marques. A exemplo do que já vemos expresso no «Leituário da Sé de Lamego», recolhe também informações relativas a propriedades, foros e direitos, traduzindo as preocupações que moveram os capitulares tudenses à realização daquele documento ${ }^{47}$.

\section{Das colheitas do bispado de Coimbra: um censual do século XIV}

De acordo com o que fica expresso, o mais antigo documento da diocese de Coimbra hoje conhecido e a que podemos chamar de censual acha-se lançado num caderno que foi reunido a um outro, sem que saibamos exactamente quando, sendo ambos encadernados a carneira. O manuscrito tem hoje a cota Mesa da Consciência e Ordens, Ordem, Ordem de Cristo/ /Convento de Tomar, livro 264, do Arquivo Nacional da Torre do Tombo ${ }^{48}$.

${ }^{46}$ Cf. Cândido Augusto Dias dos Santos, O censual da mitra do Porto, segundo códice do antigo Arquivo da Comissão Auxiliar da Administração dos Antigos Bens Cultuais, hoje no Arquivo Distrital do Porto.

${ }^{47}$ Cf. José Marques, "O censual do cabido de Tui para o arcediagado da Terra da Vinha: 1321”. Bracara Augusta. Braga. 34 (1980) 447-482, 3 est., segundo ANTT: Corporações Religiosas, Colegiada de Santo Estêvão de Valença, mç. 1, n. ${ }^{\circ} 30$, também publicado in Idem, Relações entre Portugal e Castela nos finais da Idade Média. Lisboa, Fundação Calouste Gulbenkian; Junta Nacional de Investigação Científica e Tecnológica, 1994, p. $65-104$.

${ }^{48}$ Anteriormente achava-se incluído no maço 82. Cf. Maria do Carmo Jasmins Dias Farinha; Anabela Azevedo Jara, Mesa da Consciência e Ordens. Lisboa, Instituto dos Arquivos Nacionais / Torre do Tombo, Direcção de Serviços de Arquivística, 1997, p. 285. 
No pergaminho que lhe serve de capa foi lançada, por mão do século XVI, a epígrafe: «Liuro das colleitas que han de pagar has igrejas do bispado de Cojnbra» ${ }^{49}$.

Nenhum elemento interno permite relacionar o pequeno códice com a instituição a que respeita o fundo onde hoje se encontra arrumado. Mesmo sendo evidente que também a Ordem de Cristo deteve o direito de padroado de igrejas no bispado de Coimbra, ainda herança da Ordem do Templo, o facto, por si só, não justifica a associação que constatamos. Aliás, a primeira parte do manuscrito actual, constituído por um caderno com dimensões diferentes daquele outro em que foi lançado o censual, reconduz à mesma instituição, que não é outra que a própria diocese de Coimbra e, nesta, o seu bispo. Com efeito, tal caderno, muito mutilado, aliás, recolhe registos de colheitas devidas ao prelado conimbricense, exarados em diferentes momentos, por mãos que poderemos situar, dentro do século XIV, até 1384, término do episcopado de D. Juan Cabeza de Vaca, pois os dois assentos mais avançados acham-se lavrados em castelhano ${ }^{50}$. Colheitas que, será também de observar, não se reportam apenas às igrejas da Ordem de Cristo, mas a outras dependentes de diversas instituições, mosteiro de Santa Cruz de Coimbra incluído, e, o que será porventura bem mais significativo, também referentes aos vassalos dos coutos episcopais ${ }^{51}$. A natureza diocesana e prelatícia do manuscrito não oferece, por isso, qualquer dúvida.

\footnotetext{
${ }^{49}$ A lápis acham-se lançadas as anotações que se seguem: «Cristo Tomar C. $25 », ~ « C . ~ 3$ - M. 1 - Doc. 1», «século 14», «Tomar / Cristo, 19». No recto do fol. 1 «livro 264».

${ }^{50}$ Embora não excluamos a hipótese de os referidos assentos terem sido lavrados anteriormente, por exemplo no pontificado de D. Pedro Tenório, prelado que se revelou zeloso dos rendimentos episcopais, como o testemunha um documento editado por Maria Helena da Cruz Coelho, pelo que não admiraria que outros instrumentos de administração diocesana pudessem, porventura, ter sofrido actualização ao seu tempo. Cf. Maria Helena da Cruz Coelho, O Baixo Mondego em finais da Idade Média, vol. 2, p. 791-793. Para a figura do prelado ver, entre outros, Manuel Augusto Rodrigues, "D. Pedro Tenório (1371-1378) segundo o Livro das idas dos bispos da sé de Coimbra". In Luís Adão da Fonseca; Luís Carlos Amaral; Maria Fernanda Ferreira Santos, coord., Os reinos ibéricos na Idade Média: Livro de homenagem ao Professor Doutor Humberto Carlos Baquero Moreno. Porto, Livraria Civilização Editora, 2003, vol. 2, p. 827-834.

${ }^{51} \mathrm{O}$ caderno abre com a epígrafe: «Estas som as colheytas que o bispo de Coimbra ha d'aver en cada huu anno que son tousadas [sic] tamber dos concelhos dos seus coutos
} 
Um dos problemas que o censual coloca é o relativo à sua datação, que não se acha expressa, nem se resolve por recurso a uma apreciação da escrita, atribuível a mão da segunda metade do século XIV. Sem nos determos numa análise detalhada do que diz respeito a cada uma das igrejas, das capelas e dos mosteiros nele inclusos, ou dele ausentes, que também para umas e outros não faltam elementos documentais, queremos dedicar alguma atenção a algumas notas que permitem aferir elementos para proposta de uma datação. O primeiro desses elementos diz respeito à «capella de dona Betaça», que no censual se acha taxada com vinte libras. Ela não é anterior ao decesso de D. Vataça Lascaris. E este terá ocorrido em 21 de Abril de 1336, segundo registo do Livro das Kalendas, que lhe comemorava o óbito como benfeitora da sé de Coimbra, que a senhora elegeu como igreja funerante e onde ainda hoje se encontra o seu túmulo ${ }^{52}$. O segundo aspecto a equacionar prende-se não com o censual propriamente dito mas com o elenco das igrejas e respectivos padroeiros, que prolonga aquele outro docu-

commo das Eygreias de Leyrea e de seu termho e das Eygreias da Ordem de Christo e d'outras Eygreias do bispado», lançadas como passamos a elencar, advertindo para a circunstância de os fólios não se encontrarem numerados: concelho de Avô (fol. 2r-2v), igreja de Tentúgal (fol. 2v), igreja de São Pedro do Rego da Murta (fol. 2v-3r), igreja de Arega (fol. 3r), Leiria, único texto em latim (fol. 3r-3v), igrejas de Espite, de Vila Galega, de Vermoim, de Colmeias, do Souto (fol. 3v-4r), igreja de Abiul (fol. 4r), igrejas de Pombal (fol. $4 \mathrm{v}$ ), de Redinha (fol. 4r-4v), de Dornas (fol. 5r), de Soure (fol. 5r-5v, com assento de uma segunda colheita), de Ega (fol. 5v), de Puços (fol. 6r); registo de procurações das igrejas de Ferreira, Águas Belas, Alvaiázere, Maçãs do Caminho e Maçãs de Dona Maria, estando incompleto o apontamento relativo a Ferreira (fol. 6r); colheitas do couto de Lavos, do Louriçal, de Reveles (fol. 6v), de Ossela (fol. 7r); carta de composição sobre a colheita, entre o bispo D. Pedro e os seus vassalos de Pedrulha e de Casal Combra, datada de 1301 (fol. 7r); colheita dos vassalos do bispo no burgo da Mealhada (fol. 7r), dos da Vacariça (fol. 7v), dos do couto de Barrô (fol. 8r); colheita de Santa Maria de Vagos (fol. 8r), de Mello (fol. 8v); «serviço» de Arazede (fol. 8v) e registo relativo a Soure (fol. 9r); colheita da igreja de Cantanhede e da igreja de Aveiro, lançadas em castelhano (fol. 9v); seguem-se pequenas anotações, todas canceladas (fol. 10r-10v), tal como sucede, aliás, com vários dos assentos relativos às colheitas.

${ }^{52}$ Cf. Maria Helena da Cruz Coelho; Leontina Ventura, "Vataça: Uma dona na vida e na morte". Revista da Faculdade de Letras: História. Porto. III série. 3 (1986) 159-193. Idem, "Os bens de Vataça: Visibilidade de uma existência". Revista de História das Ideias. Coimbra. 9: 2 (1987) 33-77. 
mento, embora nem sequer referencie todas as igrejas diocesanas, pois que lhe falta algo mais que uma centena daquelas instituições. Atenderemos alguns casos, tendo em vista o problema enunciado.

A igreja de São Martinho de Montemor-o-Velho, por exemplo, aparece adstrita ao mosteiro de Santa Clara de Coimbra, cujo direito de padroado, apesar de conferido à instituição por D. Afonso IV, só a partir de 1362 foi de facto exercido pelas monjas clarissas, dado que a doação régia salvaguardou a regência da igreja, por então desempenhada por um tal mestre Martinho. D. Pedro I reiteraria, em 1357, a mercê outorgada por seu pai, e, em 1362, apresentaria ao pontífice uma súplica para que fosse confirmada a união da igreja ao mosteiro, sinal de que a paróquia, entretanto, ficara vaga $^{53}$. Nesse mesmo ano, em Avinhão, o bispo de Coimbra ordenava aos seus oficiais e ao cabido que procedessem ao reconhecimento do mosteiro de Santa Clara de Coimbra como padroeiro da igreja, dando, da sua parte, positiva anuência à vontade do rei. Mesmo à vista da mercê protagonizada por D. Afonso IV, só aquele acto episcopal justifica o averbamento do direito de padroado das clarissas no documento que nos ocupa, o que não permite recuar o ano de 1362 para a sua produção.

São também várias as igrejas que, na mesma fonte, aparecem tuteladas por um conde de Barcelos e por um infante, cuja identificação nem se acha expressa, nem parece linear estabelecer sem aturado exame, que não podemos encetar aqui. Encontram-se, no primeiro caso, as igrejas de Santo Isidoro de Eixo, São Paio de Requeixo, Santa Maria de Espinhel, São Lourenço do Bairro, São Miguel de Penela, Santa Eufémia, do mesmo lugar, Santa Maria de Aguda e São Salvador de Miranda do Corvo; no segundo, as de São Miguel de Oliveira do Bairro, São Tomé de Penalva de Alva, Santa Maria de Covas e Santa Maria de Bobadela. A referência ao conde, seja ele quem for, parece indiciar que tal elenco é anterior à constituição do ducado de Bragança, com que foi agraciado o titular barcelense em 1401, sendo que, no extremo oposto, poderemos considerar a pessoa do conde

${ }^{53}$ Cf. ANTT: Corporações Religiosas, O.F.M., Província de Portugal, Convento de Santa Clara de Coimbra, documentos particulares, mç. 6, n. ${ }^{\circ} 14$. 
D. Pedro, matrimoniado com D. Branca Peres. Herdeira, por sua mãe Constança Mendes, do conde Gonçalo Garcia de Sousa, último dos Sousãos que deteve o padroado das igrejas referidas, este passou ao marido, que lhe sobreviveu. Todavia, o falecimento de D. Pedro em 1354, tendo em consideração o que ficou dito a respeito da igreja de São Martinho de Montemor-o-Velho, exclui a possibilidade de se identificar o anónimo conde com o autor do mais desenvolto dos Livros de Linhagens medievos. Mais esclarecedor revela-se o núcleo de igrejas cujo padroado aparece atribuído a um infante e fixar-nos-emos tão-somente no caso da igreja de Bobadela, pois em 24 de Abril de 1366, segundo registo da Chancelaria do rei D. Pedro I, teve lugar a apresentação do clérigo Diogo Gonçalves à igreja referida, feita pelo infante $\mathrm{D}$. João, que cremos poder identificar como o infante do elenco conimbricense ${ }^{54}$.

Em conformidade, dir-se-ia que o documento poderia, a avaliar pelo que fica expresso a respeito de São Martinho de Montemor-o-Velho e de Santa Maria de Bobadela, ter sido produzido na década de 1360, mais concretamente, entre 1362 e 1366. A questão, no entanto, mostra-se um pouco mais complexa, pois a igreja de São Paio de Requeixo, que o elenco dá como do padroado do conde de Barcelos, ainda teve apresentação régia do seu clérigo exercida por D. Pedro I em $1366^{55}$. Circunstância que nos leva a diferir para depois deste ano a produção da fonte que nos ocupa. Para termo ad quem temos presente a passagem para Castela, em 1383, quer do conde D. João Afonso Telo de Meneses, $6{ }^{\circ}$ titular de Barcelos, quer do infante D. João, filho de D. Inês de Castro, no âmbito da crise de sucessão do trono português. Poderemos, em virtude do que fica assinalado e ainda que provisoriamente, considerar o reinado de D. Fernando I como o tempo de produção do elenco das igrejas e, de igual modo, do próprio censual, pois que as duas

${ }^{54}$ Cf. Chancelaria de D. Pedro I (1357-1367). Ed. por A. H. de Oliveira Marques [et al.]. Lisboa, Instituto Nacional de Investigação Científica, 1984, doc. 1100: «Sancta maria / Carta per que o Jffante dom Joham filho del rrey dom Pedro apresentou aa sua jgreia de sancta maria de bouadella bispado de cojmbra diego gonçallvez clerigo etc»».

${ }^{55}$ Cf. Ibidem, doc. 1135. 
peças se acham intencionalmente relacionadas, de um ponto de vista de quem protagonizava a administração diocesana ${ }^{56}$.

Outro problema que o censual apresenta, e para o qual não encontramos resposta imediata, é o da distribuição das igrejas ao longo do documento, que por inteiro ignora a formalização do arcediagado do Vouga ${ }^{57}$. Às igrejas da cidade de Coimbra, cujo elenco é inaugurado com a de São João de Almedina, sucedem-se imediatamente as restantes, que estavam incluídas naquele arcediagado, dando-se ainda a circunstância de as igrejas de Montemor-o-Velho terem sido agrupadas num título específico, que antecede os arcediagados de Penela e de Seia. A questão é tão mais intrigante quanto o Catálogo das igrejas, mosteiros e comendas de 1320-1321, teve em consideração esse mesmo arcediagado para territorializar as igrejas da diocese de Coimbra ${ }^{58}$. Talvez que tudo não passe, ainda assim, de um problema aparente, pois o arcediago do Vouga, ao menos em alguns momentos passíveis de serem documentados, foi o mesmo da cidade de Coimbra ${ }^{59}$.

${ }^{56}$ Poderíamos, talvez, restringir ainda mais o intervalo à vista do caso da igreja de Santa Maria de Cernache, que o documento informa ser de padroeiros, quando em 1372, segundo Pedro Álvares Nogueira, o cabido da catedral alcançou um acordo com os mesmos a fim de que o padroado fosse exercido alternadamente, situação suficientemente importante para merecer registo, o que não aconteceu. Cf. Pedro Álvares Nogueira, Livro das vidas dos bispos da sé de Coimbra. Ed. por António Gomes da Rocha Madahil. Coimbra, Arquivo e Museu de Arte da Universidade de Coimbra, 1942, p. 128. Admitimos, no entanto, que possa ter havido negligência no registo.

${ }^{57}$ Pelo que respeita ao arcediagado do Vouga, começaremos por observar que não se conhece, exactamente, quando se deu a sua erecção, instituição ou formalização. De qualquer modo, em 28 de Julho de 1232, uma bula de Gregório IX, com o incipit Cum ad uindictam, já documenta um titular do arcediagado: «J. Archidiaconum de Vauga». Cf. A. Domingues de Sousa Costa, Mestre Silvestre e mestre Vicente, juristas da contenda entre D. Afonso II e suas irmãs, p. 190, nota 305. Para outras informações relativas ao arcediagado do Vouga tenha-se em consideração António Garcia Ribeiro de Vasconcelos, "Dignidades do cabido de Coimbra: O arcediagado do Vouga". Arquivo do Distrito de Aveiro. 6 (1940) 5-28.

${ }^{58}$ Sobre a problemática da territorialização da diocese de Coimbra na Idade Média, os seus bispos e a sua administração, ver o mais recente estudo relativo a essa instituição, da autoria de Maria do Rosário Barbosa Morujão, A Sé de Coimbra: a instituição e a chancelaria (1080-1318). Coimbra, Faculdade de Letras - Universidade de Coimbra, 2005 (dissertação de doutoramento; policopiada).

${ }^{59}$ Tal o caso de Estêvão Gomes, falecido em 1318, segundo o necrológio catedralício, «archidiaconus in ecclesia Colimbriensi ciuitatis Colimbriensis et de Vauga». Cf. Livro das Kalendas, vol. 2, p. 265. 
Mesmo não procedendo a uma detalhada análise do documento, que será talvez de empreender tendo em consideração o universo dos censuais conimbricenses, gostaríamos de fazer um pequeno exercício tendo em vista aferir, grosso modo, o peso que a prestação devida à igreja catedral tinha de facto na vida económica das instituições obrigadas à sua solvência. Vamos tomar como ponto de referência os valores consignados no Catálogo das igrejas, mosteiros e comendas de 1320-1321, aproveitando, para o efeito, os que no censual se acham expressos em moeda, já que muitos dos casos apenas referem a colheita, ou a mea colheita, sem mais, por certo em razão de ela se traduzir em géneros, que em lugar algum do documento se especificam.

\section{Igrejas da Cidade de Coimbra}

\begin{tabular}{|c|c|c|c|c|c|c|}
\hline & $\mathbf{A}$ & B & $\mathrm{C}$ & D & $\mathbf{E}$ & $\mathbf{F}$ \\
\hline São João de Almedina & 300 libras & $(09,03 \%)$ & 05 libras & $(09,25 \%)$ & $01,66 \%$ & $+00,22 \%$ \\
\hline São Pedro & 300 libras & $(09,03 \%)$ & 06 libras & $(11,11 \%)$ & $02,00 \%$ & $+02,08 \%$ \\
\hline São Salvador & 250 libras & $(07,53 \%)$ & 05 libras & $(09,25 \%)$ & $02,00 \%$ & $+01,72 \%$ \\
\hline São Cristóvão & 480 libras & $(14,45 \%)$ & 08 libras & $(14,81 \%)$ & $01,66 \%$ & $+00,36 \%$ \\
\hline São Bartolomeu & 540 libras & $(16,26 \%)$ & 10 libras & $(18,51 \%)$ & $01,85 \%$ & $+02,25 \%$ \\
\hline São Tiago & 650 libras & $(19,57 \%)$ & 10 libras & $(18,51 \%)$ & $01,53 \%$ & $-01,06 \%$ \\
\hline Santa Justa & 800 libras & $(24,09 \%)$ & 10 libras & $(18,51 \%)$ & $01,25 \%$ & $-05,58 \%$ \\
\hline TOTAL & 3320 libras & & 54 libras & & $01,62 \%$ & \\
\hline \multicolumn{7}{|c|}{$\mathbf{A}=$ Rendimento apurado pelo Catálogo das igrejas, mosteiros e comendas de 130-1321 } \\
\hline \multicolumn{7}{|c|}{$\mathbf{B}=$ Valor percentual relativo no total do rendimento, segundo a mesma fonte } \\
\hline \multicolumn{7}{|c|}{$\mathbf{C}=$ Colheita registada no censual do século XIV } \\
\hline \multicolumn{7}{|c|}{$\mathbf{D}=$ Valor percentual relativo no total das colheitas } \\
\hline \multicolumn{7}{|c|}{$\mathbf{E}=$ Valor percentual da colheita no total do rendimento, segundo as referidas fontes } \\
\hline \multicolumn{7}{|c|}{$\begin{aligned} \mathbf{F}= & \text { Variação entre o valor percentual de cada igreja no total das colheitas e do rendimento, } \\
& \text { segundo as mesmas fontes }\end{aligned}$} \\
\hline
\end{tabular}


O resultado da análise dos valores respeitantes às igrejas da cidade de Coimbra parece contrariar, em absoluto, a ideia tantas vezes afirmada a respeito dos enormes encargos em que as prestações devidas à igreja catedral e ao prelado diocesano se traduziam para as igrejas, pois o valor percentual relativo da colheita no total dos rendimentos apurados no Catálogo das Igrejas, mosteiros e comendas de 1320-1321, segundo os dados que apresentamos no quadro, oscila entre $1,25 \%$ no caso da igreja de Santa Justa e 2,00\% no das igrejas de São Pedro e de São Salvador, verificando-se, pelo meio, percentagens da ordem de 1,53\% para a igreja de São Tiago, 1,66\% para as igrejas de São João de Almedina e de São Cristóvão, e $1,85 \%$ para a de São Bartolomeu.

Todavia, como passamos a expor, aquela ideia não se mostra de todo errada, quando aferido o mesmo tipo de impacto, mas por respeito às restantes igrejas da diocese, o que exige que se procure olhar para o caso das igrejas citadinas com outro enfoque. Assim, e usando os mesmos critérios, ainda que restringindo a análise apenas a algumas igrejas, verificamos que a colheita assume no conjunto de rendimentos de igrejas rurais, independentemente do desenvolvimento urbano dos aglomerados populacionais a que se reportam, valores percentuais que oscilam entre os $11,42 \%$ no caso da igreja de Santa Maria de Loriga e os 26\% no da igreja de São Miguel de Marmeleira, com cifras que, pelo meio, vão desde os 16,25\% e 16,66\% no caso das igrejas de Barcouço e de Águas Belas, aos 25,00\% no da igreja de Santa Maria de Ansião. Apesar de a oscilação de tais valores poder ter razões muito diversas - e para isso também contribuirá a diferente natureza dos valores em causa, uns relativos a prestações fixas, outros a rendimentos de um determinado ano, que pode, ou não verificar-se noutros -, estamos a falar de taxas de impacto radicalmente diferentes das verificadas em relação às igrejas da cidade episcopal. Fora desta, sem dúvida que a colheita episcopal assumia um peso muito significativo de subtracção de rendimentos próprios das igrejas paroquiais, capelas (funerárias) ou mosteiros, desde que não sujeitos de isenção, em favor da catedral e do bispo diocesano.

O que a história das colegiadas de Coimbra nos revela é que a procuração devida ao prelado foi alvo de composição celebrada entre os priores das igrejas de Santa Justa, São Tiago, São Bartolomeu, São Cristóvão e São Pedro e seus clérigos e o bispo de Coimbra D. Egas Fafes, em 24 de Dezem- 
bro de $1256^{60}$. Faltaram as igrejas colegiadas de São João de Almedina e de São Salvador, a primeira pela razão simples de ela pertencer ao próprio prelado conimbricense, como também dá conta o censual, ao dizer daquela instituição que «he do bispo». À vista dos valores consignados no censual, verifica-se que os morabitinos acordados na citada composição foram simplesmente transpostos para libras, sem outra actualização, naquela fonte. Assim se explica o diferencial do impacto referido, entre as igrejas da cidade episcopal e as restantes.

O censual e o elenco patronal de igrejas, mosteiros e capelas objecto desta pequena nota avultam como fontes que tiveram a sua importância na vida da diocese de Coimbra em tempos medievais. Terão logrado, seguramente, cumprir o seu papel numa diocese que, depois de tantas vicissitudes, como as vividas até aos meados da centúria XIII, teve pela frente, desde então, garantias de alguma estabilidade, nos territórios que lhe conferiram entidade, nas comunidades paroquiais e religiosas que lhe deram rosto, nas

${ }^{60}$ Da composição conservam-se dois originais, um do cartório catedralício, outro do da colegiada de São Bartolomeu. Qualquer um dos instrumentos lavrados foi validado com recurso a doze selos pendentes. Cf. Maria Cristina Gonçalves Guardado, A colegiada de S. Bartolomeu de Coimbra em tempos medievais: Das origens ao início do séc. XV. Vol. 2: Apêndice documental. Coimbra, [s.n.], 1999 (dissertação de mestrado apresentada à Faculdade de Letras da Universidade de Coimbra), p. 15-16, doc. 6, segundo ANTT: Corporações Religiosas, Colegiada de São Bartolomeu de Coimbra, m. 14, n. ${ }^{\circ} 2$ e Cabido da Sé de Coimbra, 1. inc., m. 15, n. ${ }^{\circ} 32$ : «et taxavit easdem videlicet quod cum idem episcopo vel qui pro tempore peerit ecclesie Colinbriensis ad quamlibet dictarum ecclesiarum causa visitationis semel in anno accesserit et ibidem visitationis offitium exercuerit quelibet dictarum ecclesiarum scilicet Sancte Juste, Sancti Jacobi, Sancti Bartolomei teneatur episcopo Colinbriensi qui pro tempore fuerit nomine procurationis solvere sine mora in die facte visitationis predicte annuatim $X^{c e m}$ marabitinos usualis monete, ecclesia ver. Sancti Cristophori VIII ${ }^{\text {to }}$ marabitinos et ecclesia Sancti Petri VI ${ }^{\text {ex }}$ marabitinos similiter prestare teneatur. Et episcopos Colimbriensis dicta summa pecunie debet esse contentus nichil amplius nomine visitationis seu procurationis memorate requirens ad ecclesiis memoratis». 
próprias estruturas de governo e solicitude pastoral e conexos recursos de actuação, que lhe proporcionaram também vínculos de unidade. Aqueles que, em cada tempo, constroem uma comunidade, que perdura no tempo. 
I. Censual da diocese de Coimbra. II. Elenco de igrejas, mosteiros e capelas da diocese de Coimbra. [Século XIV]*.

Arquivo Nacional da Torre do Tombo / Direcção-Geral de Arquivos: Mesa da Consciência e Ordens, Ordem de Cristo / Convento de Tomar, liv. 264. Pergaminho, caderno de oito fólios não numerados, com alterações e aditamentos, alguns posteriores. Bom estado de conservação.

ๆ Estas som as col[ $h]$ eitas do bispado de Coinbra
[1] (1) It. A egreia de Sam Joham d'Almedina
çinque libras
[2] (2) It. A egreia de Sam Pedro
sex libras
[3] (2) IIt. A egreia de Sam Salvador
çinque libras
[4] (2) It. A egreia de Sam Christovam
oito libras

* Na edição foram tidos em consideração, por regra, os critérios constantes em Avelino de Jesus da Costa, Normas gerais de transcrição e publicação de documentos e textos medievais e modernos. 3. a ed., Coimbra, Faculdade de Letras - Instituto de Paleografia e Diplomática, 1993. 
[5]

[6]

[7]

[8]

[9]

[10]

[11]

[12]

[13]

[14]

[15]

[16]

[17]

[18] (12) IIt. A egreia de Pena Cova

[18] (12) IIt. A egreia de Pena Cova

/ [Fol. 1v] [20]

[21]

[22]

[23]

[24]

[25]

[26]

[27]
(2) It. A egreia de Sam Bertolameu

(2) IIt. A egreia de Sam Tiago

(2) IIt. A egreia de Sancta Justa

9 It. A capella de Françisco Lourenço

I It. A capella de dona Betaça

(3) ๆIt. O moesteiro d'Açellas d'alem da ponte

(4) IIt. A egreia d'Eiras

(6) ๆ It. A egreia de Trexamj1

q It. A egreia de Barcousso

ๆ It. A egreia de Sousellas

IIt. A egreia de Botom (9)

9 It. A egreia de Brafemes

II It. A egreia de Sazes

TIt. A egreia de Çercosa

II It. A egreia d'Almasa

ๆ It. A egreia da Marmeleira

ๆ It. A egreia d'Espinho

(13) It. A egreia de Sam Goos [sic] de

\section{Mortaagoa}

ๆ It. A egreia de Val d'Ermjgo

ๆ It. A egreia de Mortaagoa

q It. A egreia do Soveral

I It. A egreia do Burgo de Sancta Coonba

ๆ It. A egreia do moesteiro desse logo

9 It. A egreia de Sam Johanjnho (14)

II It. A egreia de Casal Coonba

ๆ It. A egreia de Mortede

ๆ It. A egreia de Bolho

ๆ It. A egreia de Vilarinho do Barro q It. A egreia da Vacariça dez libras

dez libras

dez libras

vinte soldos

vinte libras

vinte grosos

mea colheita (5)

quatro librras (7)

treze libras (8)

som isentas de

Lorvãao

quatro libras (10)

seis libras e mea (11)

colheita (8)

quareenta soldos

de çensoria e duas

librras de çera

seis libras e mea

vinte soldos

treze librras

colheita

mea colleita

mea colheita

colheita

colheita

seis libras e mea

treze librras

seis librras e mea

colheita

colheita

colheita

vinte soldos

quareenta soldos 
[36] IIt. A egreia de Çepijns

[37] It. A egreia da Ventosa

[38] It. A egreia de Ta[la]mengos

[39] IIt. A egreia de Sam Lourenço do Barro

[40] IIt. A egreia d'Anças

[41] II. A egreia d'Õoes de Barro

/ [Fol. 2r] [42] ๆ It. A egreia de Moçaros

[43] IIt. A egreia d'Arcos

[44] It. A egreia de Santiago da Mouta

[45] It. A egreia de Sam Pedro d'Avalãas

[46] It. A egreia de Sangalhos

[47] IIt. A egreia d'Ulveira

[48] ๆ It. A egreia d'Aaguada de Susãa

[49] IIt. A egreia de Barroo

[50] IIt. A egreia d'Espinhel

[51] It. A egreia de Õoes da Ribeira d'Agueda

[52] It. A egreia de Travacoo a de dar de çensura quareenta soldos

[53] IIt. A egreia de Segadãaes

[54] IIt. A egreia de Covellas

[55] IIt. A egreia d'Aagueda

[56] IIt. A egreia de Recadãaes

[57] It. A egreia de Balsama

[58] II. A egreia da Castinheira (15)

[59] IIt. A egreia de Doninhas (15) em a çara d'Alcoba paga

[60] It. A egreia de Vallongo

[61] IIt. A egreia de Lamas

[62] IIt. A egreia de Macinhata

[63] IIt. A egreia de Val Mayor

/ [Fol. 2v] [64] ๆ It. A egreia d'A Branca

[65] (1) IIt. A egreia de Palmaz

[66] IIt. A egreia d'Ossella

[67] (16) ๆ It. A egreia de Castelãaos treze librras

seis librras e mea

seis librras e mea

mea colheita

quareenta soldos

vinte soldos

mea colheita

mea colheita

colheita

colheita

colheita

mea colheita

mea colheita

mea colheita

colheita

mea colheita

tres libras

seis libras e mea

colheita

mea colheita

mea colheita

colheita

duas librras de

çera de çenssura $\mathrm{e}$

quareenta soldos

colheita

mea colheita

colheita

colheita

colheita

colheita

seis librras e mea

colheita 
[68] It. A egreia de Çepelhos

[69] It. A egreia de Maceeira da Caanbra

mea colheita

[70] It. A egreia de Roge

colheita

[71] It. A egreia de Carregosa

mea colheita

mea colheita

[72] It. A egreia de Codal

seis librras e mea

[73] It. A egreia de Villa Chãa

mea colheita

ๆ It. A egreia de Macinhata de Susmiro [?]

(15) paga

dous capoes e

hũa regeifa e hũa

cabaaça de vinho

[75] It. A egreia de Sam Martinho de Travanca (17) he issenta de graao mestre

privilegio como he

[76] It. A egreia de Figeiredo

colheita

[77] It. A egreia da Hermjda de Figeiredo

quatro libras de

çera

[78] It. A egreia de Sam Martinho de Ssal $[r]$ eu

colheita

[79] It. A egreia de Sam Mjgeel de Farmelãa

colheita

[80] It. A egreia de Sam Johane de Loure

colheita

[81] It. A egreia d'Alcorovim

colheita

[82] IIt. A egreia de Requeixo

mea colheita

[83] IIt. A egreia d'Eixo

mea colheita

[84] IIt. A egreia de Caçia

isenta de Lorvãao

[85] It. A egreia d'Esgeira

colheita

colheita

[87] (19) It. A egreia de Sam Pedro Fuim

$<$ treze> (20) librras

[88] It. A egreia de Ilhovo

seis librras e mea

[89] It. A egreia de Sam Tiago de Vaagos

colheita (21)

[90] It. A ermjda de Sancta Maria de Vaagos

colheita

[91] It. A egreia de Mjra

mea colheita

[92] बIt. A egreia d'Outil

mea colheita

[93] It. A egreia de Cordinhãa

mea colheita

[94] It. A egreia de Portunhas

colheita

[95] IIt. A egreia d'Oval

mea colheita

[96] (22) It. A egreia de Treixede

mea colheita

[97] IIt. A egreia de Cadima

colheita 
[98] IIt. A egreia de Razede

[99] (19) It. A egreia de Quiaios

[100] IIt. A egreia de Buarcos

[101] (23) It. A egreia d'Aalhada

[102] (23) II. A egreia de Mayorca

[103] (26) It. A egreia de Sancta Olalha

[104] It. A egreia de Cantanhede mea colheita

colheita

colheita

mea colheita (24)

mea colheita (25)

mea colheita

colheita

Titollo de Montemoor o Velho

[105] It. A egreia de Sancta Maria de Montemoor o Velho he do bispo

[106] IIt. A capella de Pero Mjgeez tres librras

[107] (27) It. A egreia de Sam Martinho colheita

[108] IIt. A capella d'Afomso Vasquez çinque librras

/ [Fol.3v] [109] 9It. A capella d'Enes Dominguez molher que foi de Joham de Ribellas [sic] $\quad x x$ soldos (28)

[110] It. A capella d'Afonso Dominguez da Chamoa xxx soldos (28)

[111] IIt. A capella d'A fonso Dominguez [...] vinte soldos

[112] It. A capella de Domjngos Martijns tres librras

[113] IIt. A egreia de Sam Joham de Montemoor mea colheita

[114] It. A egreia de Sam Salvador colheita

[115] IIt. A capella de Costança Peres Mynca (28) tres librras

[116] It. A capella de Tareija Dominguez trinta soldos

[117] It. A egreia da Magdalena colheita

[118] IIt. A egreia de Sam Mjgeel colheita

[119] It. A capella de donna Aviziboa tres librras

[120] It. A capella de Costança Perez tres librras

[121] It. A egreia de Tentugal colheita taixada

[122] IIt. A egreia de Sam Martinho d'Aarvore (15)he isenta de Lorvãao

[123] II. A egreia de Sam Silvestre do Canpo mea colheita

[124] II. A egreia de Sam Fagundo do Canpo mea colheita 
Titollo do arçidiagado de Penella

[125] IIt. O moesteiro de Sam Jorge paga

oiteenta grossos

[126] It. A capella de Vasco Perez Gorgomella

çinque librras

[127] II. A egreia de Castel Vehegas

mea colheita

[128] IIt. A egreia de Bruscus

colheita

[129] It. A egreia de Çernache

colheita

[130] IIt. A egreia d'Açafragem

colheita

[131] IIt. A egreia de Podentes

colheita

[132] II. A egreia de Miranda

colheita

/ [Fol. 4r] [133] ๆ It. O moesteiro de Simide

[134] IIt. A egreia de Foz d'Arouçe

oiteenta grosos

colheita

[135] IIt. A egreia de Serpijs

heissentadeLorvãao

[136] IIt. A egreia do Vellarinho

colheita

[137] (29) It. A egreia de Sancta Ofemea de Penella

colheita

[138] ๆ It. A egreia da Loussãa

colheita

[139] II. A egreia de Sam Migeel de Penella

colheita

[140] II. A egreia de Poussa Foles

mea colheita

[141] IIt. A egreia de Maçãas de Camjnho

[142] IIt. A egreia da Arega

quareenta soldos

col $[h]$ eita taxada

[143] II. A egreia de Maçãas de Dona Maria

colheita

[144] IIt. A egreia d'Aag $u$ da (30)

colheita

[145] It. A egreia de Figeiroo

colheita

[146] II. A capella de Domingos Dominguez (15) priol que foy d'Arega e trage a

Vasco Martijns

[147] IIt. A egreia do Pedrogom

[148] ๆ It. A egreia de Dornas

[149] ๆ It. A egreia de Fereira

[150] IIt. A egreia d'Aguas Bellas

[151] IIt. A egreia de Sam Pedro da Mouta

[152] IIt. A egreia d'Alvaiazer

[153] (31) It. A egreia de Puços

[154] IIt. A egreia de Pelle Maa

/ [Fol. 4v] [155] ๆ It. A egreia d'Amssyom çinque librras

colheita

colheita taxada

doze librras

çinque librras

colheita taxada

colheita

colheita taxada

treze librras

dez librras 
[156] (19) It. A egreia do Alvorge

[157] IIt. A egreia de Poonbarinho

[158] IIt. A egreia do Azanbujal

[159] IIt. A egreia d'Abiul

[160] IIt. A egreia d'Espite

[161] (19)ๆ It. A egreia de Sam Ssimon de Villa Galega

[162] (19) ๆ It. A egreia de Vermuj

[163] (19) ๆ It. A egreia das Colmeas

[164] It. Na villa de Leirea sse o bispo hi for

[165] (19) It. A egreia do Ssouto

[166] It. A egreia de Lavoos

[167] (19) $\mid$ It. A egreia de Louriçal

[168] IIt. A egreia de Querade

[169] IIt. A egreia de Samuel (32)

[170] (31) It. A egreia de Poonbal

[171] (31) It. A egreia de Ssoure

[172] (31) It. A egreia da Redinha

[173] (31) It. A egreia d'Eega

[174] (31) It. A egreia de Condeixa

[175] IIt. A egreia de Seebal

[176] IIt. A egreia de Figeiroo do Canpo

[177] IIt. A egreia d'Aanerova

/ [Fol. 5r] [178] ๆ It. A egreia de Villa Nova d'Anços

[179] IIt. A egreia de Pereira

[180] IIt. A egreia do Ameal

[181] It. A egreia de Taaveiro

[182] It. A egreia de Sam Martinho do Bispo

[183] IIt. A egreia d'Antanhol

[184] It. A egreia d'Almalages

Titollo do arçidiagado $<$ de $>$ Ssea

[185] It. A egreia d'Estira

[186] (19) It. A egreia de Poiares colheita

colheita

colheita

colheita taxada

colheita taxada

colheita taxada

colheita taxada

colheita taxada

colheita taxada

colheita taxada

çinque librras

colheita taxada

quareenta soldos

mea colheita

colheita taxada

colheita taxada

colheita taxada

colheita taxada

colheita

colheita

mea colheita

mea colheita

colheita

colheita

tres librras

mea colheita

mea colheita

çinque librras

colheita

mea colheita

colheita 
[187] It. A egreia de Gõoes

[188] It. A egreia da Varzea da par de Gõoes

[189] It. A egreia d'Arganjl

[190] It. A capella de mestre Gil

[191] It. A egreia do moesteiro d'Arganil

[192] It. A egreia de Poonbeiro

[193] It. A egreia de Sam Martinho de Sanguinheda

[194] It. A egreia de Ffarinha Podre

[195] It. A egreia de Travanca de Pay Pardinho

[196] It. A egreia d'Azer

[197] It. A egreia de Sinde

/ [Fol. 5v] [198] đIt. A egreia de Tavoa

[199] IIt. A egreia d'Espaariz

[200] It. A egreia do Mouronho

[201] It. A egreia de Coya

[202] It. A egreia de Villa Cova

[203] It. A egreia d'Avoo

[204] It. A egreia da Lourossa

[205] It. Hũa capella na dicta egreia

[206] It. A egreia de Covas

[207] It. A egreia de Candossa

[208] IIt. A egreia de Mjdoes

[209] It. A egreia de Hervedal

[210] It. A egreia de Travanca da Terra de Sea

[211] It. A egreia d'Ulveirinha

[212] It. A egreia da Babedella

[213] It. A egreia de Nogeira

[214] (34) It. A egreia de Olveira d'Ospital

[215] It. Hũa capella en essa egreia

[216] It. A egreia de Lagares

[217] It. A egreia de Lagos

[218] It. A egreia de Murjna

[219] It. A egreia de Folhadoosa colheita

mea colheita

colheita

çinque librras

colheita

colheita

colheita

colheita

treze librras

colheita (33)

colheita

colheita

seis librras

mea colheita (17)

colheita

treze librras

colheita

colheita

tres librras

colheita

çinque librras

colheita

colheita

mea colheita

seis librras e mea

mea colheita

colheita

colheita

çinque librras

mea colheita

treze librras

vj librras e mea 
[220] It. A egreia de Sam Paio de Codeso

$$
\text { anexadas }
$$

/ [Fol. 6r] [221] ๆ It. A egreia de Penalva

[222] IIt. A egreia de Samdemj1

[223] IIt. A egreia d'Alvito

[224] II. A egreia de Loriga

[225] IIt. A egreia de Valazim

[226] IIt. A egreia de Sam $<$ Romãao $>$ (36)

[227] IIt. A egreia da Varzea

[228] IIt. A egreia de Sancta Ovaya

[229] IIt. A egreia de Sameiçe

[230] IIt. A egreia do Sseixo

[231] ๆ It. A egreia de Tourãaes

[232] II It. A egreia de Sea

[233] It. A egreia de Sancta Coonba da par de Ssea

[234] IIt. A egreia de Moymenta

[235] IIt. A egreia de Mangalde

[236] It. A egreia de Sancta Marinha

[237] It. A egreia de Paaços

[238] II. A egreia de Villa Nova

[239] IIt. A egreia d'Arcozello

[240] It. A egreia de Vinhoo

[241] ๆ It. A egreia de Sam Giãao de Gouvea

/ [Fol. 6v] [242] ๆ It. A egreia de Sam Pedro de Gouvea

[243] IIt. A egreia de Nabaaes

[244] IIt. A egreia de Nabainhos

[245] IIt. A egreia de Melloo

[246] IIt. A egreia de Sam Paio

[247] It. A egreia de Felgosinho

[248] IIt. A egreia de Fegeiroo d'Ospital

[249] IIt. A egreia de Villa Cortes

[250] IIt. A egreia de Villa Franca

[251] IIt. A egreia de Juncaaes

[252] IIt. A egreia de Misquitella vj libras (35)

colheita

mea colheita

quareenta soldos

quatro librras

tres librras

colheita

colheita

treze librras

sseis librras e mea

colheita

colheita

colheita

seis librras e mea

mea colheita

tres librras

treze librras

seis librras e mea

colheita

mea colheita

tres librras

mea colheita

colheita

oito librras

seis librras

seis librras e mea

doze librras

colheita

seis librras e mea

seis librras e mea

seis librras e mea

quatro librras e mea

colheita 
[253] It. A egreia de Sancta Maria de Linhares colheita

[254] II It. A egreia de Sancto Isidro de Linhares colheita

[255] II. A egreia de Toricoo tres librras

[256] It. A egreia de Sam Pedro de Linhares viij. ${ }^{\circ}$ librras

$$
- \text { II }-
$$

/ [Fol. 7r] I Estas egreias ssom do bispo

[1] IIt. Sam Joham d'Almedina

[2] II It. Sancta Maria de Palmaz

[3] II It. Sanct'Andre de Baroo

[4] IIt. Sancta Coonba do Monte

[5] IIt. Sam Joham de Çepelhos

[6] It. Sam Vicente da Vacariça

[7] II. Sam Martinho de Cassal Coonba

[8] IIt. Sancta Maria de Barcouso

[9] IIt. Sam Martinho do Couto

[10] It. Sam Lourenço de Taaveiro

[11] IIt. Sancta Maria de Lavoos

[12] II. Sam Pedro de Bruscos

[13] IIt. Sancta Maria d'Alvaiazer

[14] IIt. Sam Pedro de Lourosa

[15] It. Sancta Maria de Nogeira

[16] ๆ It. Sam Romãao

[17] IIt. Sancta Maria de Mjdoes

Titollo das egreias delRey

[18] IIt. Sam Salvador de Montemoor

[19] IIt. Sancta Maria Magdalena

[20] II. Sam Mjgeel 
[21] It. Sancto Andre da Misquinhata

[22] It. Sam Paaio de Figeireda

[23] It. A romagem de Figeiredo

[24] It. Sam Mjgeel d'Aaveiro

[25] It. Sam Tiago de Vaagos

[26] It. Sancta Olalha d'Aagueda

[27] It. Sam Pedro d'Avalãas

[28] IIt. Sam Paaio d'Arcos

[29] It. Sancti Cucufatj da Mouta

[30] It. Sam Momede [sic] de Velho

[31] It. Sam Mjgeel de Vilarinho

[32] It. Sam Pedro de Vallongo

[33] It. Sancta Maria de Lamas

[34] It. Sam Pedro de Segadãaes

[35] It. Sancta Maria de Mortaagoa

[36] It. Sam Mjgel do Soveral

[37] It. Sam Tiago do Codal

[38] It. Sancta Maria de Pena Cova

[39] IIt. Sancto Andre da Cordinhãa

[40] It. Sancta Maria de Pousa Foles

[41] It. Sam Silvestre da Lousãa

[42] It. A egreia de Villa Nova d'Anços

[43] It. Sanct'Ilafonso de Anhovra

[44] It. Sancto Estevom de Pereira

[45] It. Sancta Maria de Samuel

[46] It. Sam Gees do Burgo d'Arganjl

[47] It. Sam Pedro de Sandemjl

Titollo das egreias do cabidoo

[48] It. Sam Pedro d'Aalhada

/ [Fol. 7v] [49] IIt. Sam Salvador de Mayorca

[50] It. Sam Mjgeel de Villa Nova de Moçaros

[51] It. Sam Pedro de Taamengos 
[52] It. A egreia de Sancta $\mathrm{Ma}<$ rtinho $>$ (37) de Mortede

[53] It. Sam Joham de Çepijns

[54] It. Sancta Maria d'Ancas

[55] It. Sam Pedro do Spinho

[56] It. A egreia do Pedrogom

[57] It. Sam Pedro de Vilarjnho

[58] It. Sam Pedro de Folhaadoosa

[59] It. Sam Salvador de Tourãaes

Titollo doutras egreias

[60] It. O moesteiro de Çeiça

d'Alcobaça

[61] It. O moesteiro de Sam Paulo

idem

[62] It. O priorado das Colmeas

de Sancta Cruz a

confirma o bispo

[63] It. O moesteiro de Sam Jorge

[64] It. O moesteiro d'Arganjl

confirma o bispo

[65] IIt. O moesteiro de Sancta Ana

idem

[66] It. Sam Martinho de Montemoor

vigita o bispo

[67] It. A vigararia de Tentugal

de Sancta Clara

[68] It. Sam Silvestre do Canpo

de Çeiça he

[69] It. Sancta Olalha

de padroeiros he

[70] It. Sam Martinho de Ssal $[r]$ eu

de Sancta Cruz

[71] It. Sam Mjgel da Fermela

de Lorvãao

[72] It. Sam Joham de Louro

patronorum

patronorum

73] It. Sancta Maria de Alcoravjm

de Sancta Cruz

[74] It. Sam Joham de Caçia

de Lorvãao

[75] बIt. Sancto Andre d'Esgeira

de Lorvãao

[76] IIt. Sam Felizes

de Sancta Cruz

[77] It. Sancto Ysidro d'Eixo

do conde de

Barçelos

[78] It. Sam Paio de Requeixo

do conde he

[79] It. Sancta Maria d'Espinhel

idem

[80] It. Sancta Olalha d'Aagoada

de Sancta Cruz 
[81] It. Sam Mjgel d'Olveira

[82] It. Sam Vicente de Sangalhos

[83] It. Sam Lourenço de Barro

[84] It. Sancta Maria da Ventosa

[85] It. Sam Gees de Mortaagoa

[86] It. Sancto Andre de Val d'Ermjgio

[87] It. Sam Pedro d'Oussela

[88] It. Sam Pedro de Castelãaes

[89] It. Sam Salvador de Roge

[90] It. Sam Mateus de Botom

[91] It. Sam Tiago de Treiximjl

[92] It. Sam Tiago d'Eiras

/ [Fol. 8r] [93]

[94]

[95]

[96]

[97]

[98]

[99]

[100] It. Sam Joham de Figeiroo

[101] It. A egreia d'Aarega

[102] It. Sam Pedro < da Murta $>$

[103] It. Sam Salvador de Mjranda

[104] It. Sam Mjgeel de Foz d'Arouce

[105] It. Sam Tiago d'Almalages

[106] It. Sam Justo do Ameal

[107] It. Sancta Maria de Cernache

[108] IIt. A egreia d'Abeul

[109] IIt. Sam Joham de Pelle $<$ Maa $>$

[110] It. Sancta Maria d'Ansiom

[111] It. A egreia do Alvorge

[112] It. A egreia de Poonbarjnho

[113] It. Sancta Maria do Azanbujal do infante

de Sancta Clara

comjtis est

de Sam Salvador

he

de Lorvãao

Sancta Cruz

de Grijoo he

hũa vez o bispo

e outra o cabidoo

patronorum

de Loorvãao

d'Arouca

de Lorvãao he

de Sancta Cruz

de Sancta Cruz

de Lorvaao

patronorum

do conde

idem

idem

d'Arganil

patronorum

d'Arganjl he

comjtis [est]

de Lorvãao

de padroeiros

de Sam Jorge

patronorum

de Lorvãao

patronorum est

de [Sancta] Cruz

idem

patronorum

de Sancta Anna 


\begin{tabular}{|c|c|c|}
\hline [114] & ๆ It. Sancta Maria de Podentes & patronorum \\
\hline [115] & ๆ It. Sam Pedro de Bruscos & $\begin{array}{l}\text { do bispo e de } \\
\text { patronorum }\end{array}$ \\
\hline [116] & ๆ It. Sancta Maria d'Antanhol & \\
\hline$[117]$ & ๆ It. Sam Mjgel da Çegoueira (9) & de Simjde \\
\hline$[118]$ & ๆ It. Sam Salvador do Souto & de $[$ Sancta $]$ Cruz \\
\hline [119] & ๆ It. Sancta Maria de Seira & patronorum \\
\hline [120] & ๆ It. Sancta Maria de Gõoes & patronorum \\
\hline [121] & ๆ It. Sam Tome de Pena Alva & infante \\
\hline [122] & ๆ It. Sam Martinho da Sanginheda & \\
\hline [123] & I It. Sam Pedro de Farinha Podre (9) & patronorum \\
\hline [124] & ๆ It. A egreia de Tavoa & patronorum \\
\hline [125] & ๆ It. Sancta Maria de Covas & infante \\
\hline [126] & IIt. Sancta Maria de Bevedella & infante \\
\hline [127] & ๆ It. Sancta Maria d'Arcozello & patronorum \\
\hline 8] & ๆ It. Sancta Maria de Misquitella & patronorum \\
\hline
\end{tabular}

NOTAS: (1) à margem: do bispo he (2) à margem: collegio he (3) à margem: de Claraval (4) à margem: de Lorvaao (5) à margem: Sam Joham (6) à margem: do moesteiro d'Arouca (7) à margem: Sam Tiago (8) à margem: Sancta Maria (9) unida, por chaveta, à ementa anterior (10) à margem: Sam Johane (11) à margem: Sancto Andre (12) à margem: delRey he (13) à margem: de Lorvaao he (14) correcção posterior, talvez de Joham (15) corrigido posteriormente (16) à margem: hũa capella de Castellãaos de Sancha Martijns paga xl soldos, em registo posterior (17) emendado (18) à margem: d'Abis (19) à margem: de Sancta Cruz (20) riscado: tres (21) registo acrescentado à margem, pela mesma mão (22) à margem: nom sabemos hu he, acrescento posterior, com chaveta a unir as igrejas de Ovar e Treixede (23) à margem: do cabidoo he (24) à margem: Sam Pedro (25) à margem: Sam Salvador (26) à margem: de Sancta Marynha (27) à margem: de Sancta Clara (28) acrescento posterior (29) à margem: Avys (30) letra $u$ por mão posterior (31) à margem: de Christo (32) corrigido posteriormente, de Mjgel (33) segue-se rasura (34) à margem: d'Avys, riscado (35) a ementa foi acrescida posteriormente, dando conta da anexação das duas igrejas e corrigindo o respectivo valor, sendo que a originalmente dedicada a São Paio de Codeço foi riscada: $\mid$ It . A egreia de Sam Payo de Codeso vinte soldos (36) emendado sobre Ronãao (37) correcção sobre Maria, mas sem emenda na concordância do título hagiográfico. 